\title{
Z Kuşağının Yazarlık Denemesi: Wattpad Platformunda Yer Alan Genç Kız Hikayelerindeki Karakter ve Davranış Temsillerinin İncelenmesi
}

\author{
DOI: $10.26466 /$ opus. 894500 \\ Burak Acar $^{*}$ - Zehra Karahan**- Gülseren Yalçın***- \\ Ayşe Nur Yorulmaz ${ }^{* * * *}$ - Ömer Miraç Yaman ***** \\ * Arş. Gör., İstanbul Üniversitesi-Cerrahpasa, Sağlık Bilimleri Fakültesi, İstanbul/Türkiye \\ E-Posta: acarburak.tr@gmail.com \\ ORCID: $\quad 0000-0003-4765-3319$ \\ ** Sosyal Çalışmacı, Kadınlarla Dayanışma Vakfı- KADAV , İstanbul/Türkiye \\ E-Posta: zehrakarahanalp@gmail.com $\quad$ ORCID: $\quad$ 0000-0002-4642-2124 \\ *** Sosyal Çalışmacı, İstanbul/Türkiye \\ E-Posta: glsrnylcn00@gmail.com ORCID: 0000-0002-3466-5583 \\ **** Sosyal Çalışmacı, İstanbul/Türkiye \\ E-Posta: aysemm.yorulmaz@hotmail.com ORCID: 0000-0002-2005-8782 \\ ***** Doç. Dr., İstanbul Üniversitesi-Cerrahpasa, Sağlık Bilimleri Fakültesi, İstanbul/Türkiye \\ E-Posta: $\quad \underline{\text { omermirac@gmail.com }} \quad$ ORCID: $\quad \underline{0000-0001-9989-8575}$ \\ Öz
}

Bu çalısmanin amacl; dijital okuma-yazma sitesi olan Wattpad platformunda yer alan hikayelerdeki karakter temsilleri, olay örgüleri ve riskli davranış örüntülerini incelemek suretiyle Z kuşağı olarak tarif edilen çocuk ve ergenlerin eğilim ve ilgi alanlarım keşfetmek amaçlanmaktadır. Bu kapsamda genç kız edebiyatı kategorisinde 150.000 ve üzeri beğeni sayısına ulaşan, tamamlanan ve henüz fiziksel olarak kitap haline dönüşmeyen on beş kitap içerik analizi yöntemiyle incelenmiştir. Sağlıklı olmayan aile temsilleri, cinsiyet özelliklerinin öne çıkartıldığı kadın ve erkek temsilleri, madde kullanımı, suç, şiddet, intihar gibi riskli davranışlar, erken yaşta cinsel birliktelikler, pornografik sunumlar, tecavüz gibi cinsel içerikli davranıslar hikayelerde öne çıan içerik özelikleridir. Kitaplarda yer alan içerikler riskli davranışlar bağlamında çocuklar ve gençler için özendirici olma özelliği taşımaktadır. Bununla birlikte var olan kitaplar, Z kuşağının düşünce ve beklentilerini anlama; karşılaştıkları ailevi, ilişkisel ve duygusal problemlerin neler olduğunu keşfetme ve bu sorunlarla nasıl baş ettikleri ve çözüm yollarına yönelik geniş bir veri havuzu niteliği taşımaktadır. Sonuç olarak, çocuklarm gelişim özellikleri dikkate alınarak Wattpad gibi sanal platformlarm denetimlerinin yapılacağı, kullanıcıların ve ailelerin bilgilendirileceği yöntemlerin geliştirilmesi önemlidir.

Anahtar Kelimeler: Wattpad, Genç Kız, Z Kuşă̆ı, Pornografi, Riskli Davranışlar. 


\title{
The Attempt of Authorship in Generation Z: An Investigation of Character and Behavioral Representations in the Young Girl Stories on Wattpad Platform
}

\begin{abstract}
*
Abstract

The aim of this study is to explore the desires and fields of interest of children and teenagers who are described as Generation $Z$ by addressing character representations, storylines and risky behavioural patterns found in Wattpad which is a digital reading-writing website. In this scope, in the chick lit category, completed fifteen books, which have reached 150,000 or more likes, but have not been physically transformed into books yet, were reviewed through the content analysis method. Unhealthy family representations, female and male representations where gender characteristics are emphasized, risky behaviours such as substance use, crime, violence, and suicide, early sexual intercourse, pornographic presentations, sexual behaviours such as rape are prominent content features in the stories. The contents in the books encourage children and adolescents to engage in risky behaviours. However, existing books are a large data repository that includes understanding the thoughts and expectations of Generation $Z$, discovering the familial, relational and emotional problems they face and how to handle and to provide solutions to them. As a result, taking into consideration the developmental characteristics of children, it is important to develop methods whereby virtual platforms such as Wattpad will be inspected and its users and families will be informed.
\end{abstract}

Key Words: $\quad$ Wattpad, Young Girl, Z Generation, Pornography, Risky Behaviors. 


\section{Giriş}

Siyasal olaylar ve politik dönüşümler, sosyal ve teknolojik değişimler insanların beklentilerini, satın alma ve tüketim alışkanlıklarını, çalışma yaşamına yönelik tutum ve algılarını, yerel ve evrensel düşünce tarzlarını etkilemekte hatta dönüştürmektedir. Etki ve dönüşümün ölçülmesi, gözlemlenmesi ve karşılaştırılabilmesi için ise kuşak veya nesil hareketlerinin özellikleri, onların tutum ve davranışlarının çok iyi analiz edilmesi önemlidir. Bu sebeple öncelikle kuşak veya nesil kavramın ne anlama geldiği, nasıl ve neye göre belirlendiğinin doğru anlaşılması gerekmektedir. Kuşak kavramı çok bilinen anlamıyla "yaklaşık olarak aynı yıllarda doğmuş, aynı çağın şartlarını, dolayısıyla birbirine benzer sıkıntıları, kaderleri paylaşmış, benzer ödevlerle yükümlü olmuş kişilerin topluluğu" olarak tanımlanmaktadır (Türk Dil Kurumu [TDK]). Keleş (2011, s.130), teknolojinin gelişmesi, çalışma türünün ve seçeneklerinin değiş̧mesi, toplumsal değer ve öğretilerde yaşanan farklılaşmayla kuşakların 20-25 yılı temsil edebildiğini, daha sonrasında kuşakların bir dönüşüme uğradıklarını belirtmektedir. Her ne kadar kuşak kavramı; benzer zamanlar, sorunlar, kader, kültür ve coğrafya gibi bir ortaklığın yerel düzeyde öne çıkarılmasını temsil etmekteyse de bugün artan teknolojik imkanlar etkileşimi kolaylaştırmakta, dönüşümleri hızlandırmakta, davranışları ve tutumları benzer hale getirebilmektedir (Arslan ve Nur, 2018, s.331-332). Kuşakların yerelliğine verilebilecek örneklerden birisi 2. Dünya Savaşı sonrası ABD'de yaşanan bebek nüfusundaki artışa atfen o dönemde doğanlar için bebek patlaması (Baby Boomers) kuşağı kavramının kullanılmasıdır (Twenge, 2013, s.11). Bu kuşağın ortaya çıkışı ve sonuçları kendine özgüdür ve evrensel bir temsiliyeti bulunmamaktadır. $Y$ kuşağ1 ve 1990'ların sonundan itibaren doğanları temsil eden Z kuşağ1nın önceki kuşaklardan farklı olarak yer ve zaman bağlamında bir kuşak tanımı içerisine yerleştirilmesi zordur (Sladek ve Grabinger, 2013, s.2). Z kuşağ 1 , önceki kuşaklarda var olan yerel ve kültürel dinamiklere sahip olmanın aksine tutumları, davranışları ve öğrenme alışkanlıklarıyla çok uluslu bir kültürün evrensel temsilcisi haline gelmiştir. Hızlı değişim, etkileşim ve dönüşümün merkezinde yer alan $Z$ kuşağı önceki 'kuşak'lardan bu yönüyle farklı özelliklere sahiptir. Z kuşağını bilinen diğer kuşaklardan ayıran en temel özellik, teknolojinin içine doğan ilk nesil 
olmalarıdır (Rothman, 2016, s.3). Teknolojinin içine doğmaları, teknoloji araçlarının günlük yaşamlarında vazgeçilmez bir yere sahip olması ve böylelikle algılarında, anlayışlarında farklılıkların oluşması Z kuşağını bu araştırmanın da odağı haline getirmektedir (Sarığlu ve Özgen, 2018, s.1068). 1995 yılından önce doğmuş ve harita okuyarak yönünü bulan, $\mathrm{CD}$, kaset veya plak satın almak için beklemek zorunda olan nesil; yön bulmak için navigasyon eklentisini yeterli gören, saniyeler içinde tüm yeni kitap, şarkı, film gibi eğlence araçlarına ulaşılabilen çocuklara sahip oldular (Seemiller ve Grace, 2019, s.39). ABD'de yapılan bir araştırmaya göre çocuklarda ortalama telefon sahibi olma yaşı 12 'dir ve $Z$ kuşağındaki çocukların \%78'i bir akıllı telefona sahiptir (Google, 2016). 4 yaşından küçük çocuğa sahip ebeveynler ile yapılan bir çalışmaya göre çocuklarının 1/3'ünden fazlası ilk doğum günlerinden önce bir tablet veya akıllı telefon kullanmışlardır (Sifferlin, 2015). 8 yaş altındaki çocuklarla yapılan bir başka araştırmada ise çocukların \%42'sinin kendisine ait bir tablete sahip olduğu ve bu çocukların yarısından fazlasının 5-8 yaş aralığında bulunduğu tespit edilmiştir (Common Sense Media, 2017, s.18). Sonuç olarak Z kuşağı, yazılı not almayan, bilgisayar kayıtlarına güvenen, yüz yüze sorudan ziyade çevrimiçi soru sormaya eğilimli olan, eposta, mesaj gibi yanıt beklenilen araçları sevmeyen Twitter, Facebook, Whatsapp vb. araçlarla anlık bilgi ve iletişimde ısrarcı olan, akıllı telefon kullanımından dolayı kol saati dahi kullanmayan, teknoloji ile iç içe geçmiş bir nesil olarak tanımlanabilmektedir (Rothman, 2016, s.4; Duseve Duse, 2015, s.696). Günlük yaşamlarında teknolojik araçlar ve internet kullanım sıklıklarını göz önünde bulundurmak da Z kuşağının gerçekliğine tanıklık etmek açısından önemlidir. Öyle ki bir araştırmaya göre $Z$ kuşağının tamamının günde 1 saatten fazla çevrimiçi olarak yer aldığı, $\% 46$ 'sının ise günde 10 saatten fazla çevrimiçi bulunduğu sonucuna ulaşılmıştır (Sladek ve Grabinger, 2013, s.2). Ülkemizde benzer şekilde örneklemin yarısının 21-22 yaş grubu gençlerin oluşturduğu 1254 üniversite öğrencisi ile sosyal medya kullanımları üzerine kapsamlı bir çalışma yapılmıştır. Gençlerin \%57,1' inin internete her an bağlı durumda olduğu, \%31,9'unun ise günde bir kez internet kullandığı sonucuna ulaşılmıştır. Dolayısıyla gençlerin \%90'ının her gün internet ile temas halinde olduklar1 görülmektedir (Babacan, 2015a, s.138). Türkiye İstatistik Kurumu'nun (TÜİK) 2020 yılı için yayınladığı Hanehalkı Bilişim Teknolojileri 
(BT) Kullanım Araştırması'na göre de 16-24 yaş arasındaki gençlerin $\% 94,2$ 'sinde cep telefonu bulunmaktadır. Yine aynı yaş döneminde son 3 ayda bilgisayar kullanma oranı \%68,2, internet kullanım oranı ise \% 91,8'dir. Z kuşağ1 teknolojinin içine doğmakla kalmamakta özellikle internet teknolojileri kullanımında en büyük tüketim grubunu oluşturmaktadir.

Doğal olarak, Z kuşağı içine doğduğu teknolojik araçlara sahip olmay1 ve sanal platformları sıklıkla kullanmayı kendini ifade etmenin de en etkili yolu olarak görmektedir. Valkenburg ve arkadaşlarının (2005, s.398) yaptığı bir çalışmaya göre; sosyal medya platformları gençler tarafından kendilerini tanıyıp keşfetmek ve sosyalleşmek amacıyla kullanılmakta olup sadece teknolojik olarak değil aynı zamanda kimliklerini ve benliklerini keşfetmelerine yardımcı olacak psikolojik imkanlar da sağlamaktadır. Dolayısıyla iş, aile veya eğitim yaşamında başarılı olamayan veya tatmin sağlayamayan bireyler sosyal medya platformları aracılığıyla anonimleşebilmekte ve psikolojik tatmin sağlayabilme imkanı bulabilmektedir (Babacan, 2015b, s.40). Teknolojinin gelişmesiyle birlikte gençler kendilerini ifade etme, iletişim kurma ve tecrübelerini aktarma konusunda yoğun bir şekilde kullandıkları teknolojik araçlar bu neslin kişiliklerini tamamlayıcı bir etki oluşturabilmektedir (Vural ve Bat, 2010, s.373). Sosyal medyanın aktif bir şekilde kullanılması bireylerin hayata bakış açılarını etkilemekte ve yaşamlarına yön vermelerinde önemli rol oynamaktadır. Kullanıcılarını bir kimlik performansına yönelten sosyal medya, üyelerine kim olduklarını kendi istekleriyle ortaya koyma imkanı sunmaktadır (Okur, 2013, s.104, 101). Bu açıdan birçok birey için sosyal medya, bir kimlik inşası aracı olarak gençlerin yeni benlik alanı kurgulamasını kolaylaştırmaktadır (Çalışır ve Çakıcı, 2015, s.267).

Gençlerin kendilerini ifade etmeleri için yeni bir alan oluşturan sanal platformlar ve paylaşım siteleri ile girilen yoğun ilişkiler bazı riskleri de beraberinde getirmektedir. Bazı paylaşım platformlarının kontrol ve denetim mekanizmalarının zayıf olması kişilerin kendi sınırlarını zorlamalarına sebep olurken bireyler üzerinde de bir takım olumsuz durum ve davranışlara neden olabilmektedir. Gençleri kimlik krizine sürükleyebilen sanal ağlar, gencin toplumsal sürecinde genel kabul ve ret alanlarının birbirine karışmasına sebep olabilmektedir (Engin, 2013). Bunun yanında bu tür platformlar kontrole açı olmama yönüyle gençlik açı- 
sından bir risk faktörü oluşturmaktadır. Çok küçük yaşlardan gençlik çağına kadar birçok farklı yaş grubundan bireylerin bir araya gelebilmesine ve etkileşimde bulunabilmesine imkan sağlayabilen bu tür platformlardaki içeriklerin kontrol edilememesi ve herkese açık olması özellikle gelişimini tamamlayamamış çocukları psikolojik ve sosyal açıdan riskli hale getirebilmektedir.

Sanal platformların risklerinden bir diğeri ise narsist kişilik özelliklerini tetikleyici bir rolünün olmasıdır. Günümüzde gerçek yaşam ile sanal ortam iç içe geçmiştir. Sosyal medya kişilere ve firmalara görünürlük kazandırarak insanların sosyal ağlar aracılığıyla 'ben buradayım' demelerini sağlamaktadır. Toplumla uyumlu hale getirilme çabaları sonucu bireyler bu sanal ortamlarda 'iyiyim, mutluyum, muhteşemim, şahaneyim' gibi ifadelerle uyumlaşmaya çalışırken sosyal ağlara dahil olmaktadır. Buradaki araçlar kişinin narsistlik yönünün ortaya çıkmasına sebep olabilmektedir. Yani daha genel bir ifadeyle sosyal ağlar, araç ve ortam bakımından narsisizmi teşvik eden etkenleri içerisinde barındırmaktadır (Alanka ve Cezik, 2016, s.560). Bunun yanında sanal platformların üreticisi veya tüketicisi olan kullanıcıların siber zorbalığın birer faili ya da mağduru durumuna da dönüşebilmektedir. Kontrolsüzlüğün ve denetimsizliğin bulunduğu bazı sanal platformalar insanları hesap verilebilirliğini ve kurallara uymasını engelleyebilmektedir. Bu tür platformlarda kimliği belirsiz kişiler tarafından ortaya çıkartılan antisosyal davranışlar çocuk ve gençlerin okul ve aile ilişkilerini, psikososyal iyilik hallerini olumsuz etkileyebilmektedir. (Ekşi ve Ümmet, 2013, s.98). Ülkemizde ilköğretim öğrencilerinden üniversite öğrencilerine kadar çok çeşitli çocuk ve gençlik gruplarıyla yapılan çalışmaların ortak noktası özellikle Z kuşağını temsil eden bu grupların sanal zorbalığın mağduru ya da faili oldukları gerçeğidir (Kocaşahan, 2012; Horzum ve Ayas, 2011; Kavuk, 2011; İnselöz ve Uçanok, 2013; Fırat ve Ayran, 2016; Güngör ve Koçak, 2020). Sonuç olarak kontrolsüz ve denetimsiz bir takım sosyal platformların küçük yaştaki çocuklar ve ergenler için gelişimsel ve psikososyal açıdan ciddi bir tehdit olduğu görülmektedir. 


\section{Z Kuşağ1 Hikayeciliği: Wattpad Platformu}

Yaratıcı, üretici ve mucit özelliklerinin yanında tüketici bir kimliğe de sahip olan Z kuşağı geçmiş alışkanlık ve araçları sanal platformalar üzerinden yeniden yorumlamakta ve kendi kültürünü oluşturmaktadır. Çocukların ve gençlerin kendilerini ifade etme alışkanlıklarından birisi olan yazım biçimleri $\mathrm{Z}$ kuşağı tarafından sanal platformlara aktarılarak yeni üretim ve tüketim anlayışlarını doğurmaktadır. Bilgi teknolojilerine dayalı kültür endüstrisi de bu yeni anlayışa hizmet ederek $\mathrm{Z}$ kuşağı tarafından tüketilmesi amaçlanan çeşitli ürünler üretmektedir (Yoesoef, 2019, s.131). Okuma kültürü ve edebi eserleri bir araya getiren Wattpad bu ürünlerden birisidir. Wattpad, Z kuşağının beklenti ve ilgisini dikkate alarak hikaye, kitle ve platform üçlüsünü bir araya getirmiş ve transmedya hikayeciliğinin bir örneği olmuştur (Bazarcı, 2019, s.563). Temsil ettiği yaş itibariyle ergenlik sorunları, kimlik arayışları, varoluş problemleri, çevreyle çatışmalar, aile ve arkadaş ilişkileri gibi konularla (Asutay, 2000, s.54) öne çıkan Z kuşağı hayata bakış açıları, sorunlarını ortaya koyma biçimleri ve iç dünyalarını Wattpad gibi sanal platformlar aracıl1ğıla yansitabilme ve etkileşimde bulunabilme imkanı elde etmektedir. Wattpad, 2007 yılında okuyucuların ilgisini çekmek için Gurur ve Önyargı gibi halka açık kitaplarla hizmete girmiştir. Günümüzde her yeni üyeye kendi sesini duyurabilme ve okurlara sevdikleri hikayelerle bağlantıda kalabilmelerine imkan sağlayan sosyal hikaye platformuna dönüşmüştür. Dahası Wattpad Studios; Wattpad hikayelerini yeniden üretmek amaciyla televizyon, baskı, film vb. gibi dijital platformlarda, eğlence sektörü ile işbirliği halinde çalışan profesyonel bir yaklaşıma dönüşmüş ve büyük bir şirket haline gelmiştir (Wattpad, 2020a). Öyle ki Wattpad platformu sadece 2017 y1lında \%40 büyümüş̧ür. Wattpad Topluluğu 2020 yılı raporunda kendisini "ayda, 23 milyar dakikadan fazla süre hikayelerle meşgul olunan, yine aylık 90 milyondan fazla kullanıcı ve yazarın etkileşimde bulunduğu bir sosyal hikaye anlatma platformu" şeklinde tanımlamadığı dikkate alındığında üretim ve kurumsallığının yanında ciddi bir tüketici grubuna da hitap ettiği görülmektedir (Wattpad, 2020b). Topluluk, tüm dünyada kullanıcılarının \%90'ının Z kuşağı veya $\mathrm{Y}$ (millennial) kuşağından oluştuğunu açıklamaktadır (Wattpad, 2020a). Her ne kadar Wattpad topluluğu tarafından ülkemizin 
resmi kullanıcı ve yazar sayıları hakkında resmi bir açıklama yapılmamış olsa da bu konudaki tek bilgi, şirketin kurucu ortağı olan Allen Lau'ya dayandırılmakta ve 2015 yılına ait sınırlı bilgiler içermektedir. Öyle ki bu bilgiyi kullanan çok sayıda yazılı ve görsel medya platformalarına göre ülkemizde Wattpad kullanıcısı sayısının 3 milyondan fazla olduğu ve dünyada en fazla kullanıcı sayısına sahip ülkeler sıralamasında ilk 4'e girdiği ifade edilmektedir (Kara, 2015). Yapılan bir araştırma sonucunda Wattpad hikayelerinde en çok kullanılan diller listesinde Türkçe İngilizce, İspanyolca ve Portekizce dillerinden sonra 4.sırada yer aldığı görülmektedir (Pianzola, Rebora ve Lauer, 2020,s.10).

Wattpad gibi kullanıcılara özgürce hareket etme olanağı sağlayan uygulamalar, dış baskılardan kaçan Z kuşağının bu platformları tercih etmesine sebep olabilmektedir. Ayrıca Wattpad gençlere popüler olma imkanı sağlamaktadır. Wattpad'e erişimin kolay olması, gençlerin kendi yaşamlarını bu kurgulara yansıtmaları ve paylaştıkları hikayelere yapılan yorumlarla geri dönütler almaları bu platformun popüler hale gelmesini sağlamaktadır. Wattpad uygulamasının, kullanıcılarda hem duygusal bir hoşnutluk hem de öğrenmede doygunluk sağladığı, kullanıc1nın hikayelerde kendinden bir şeyler bulmasını sağlarken aynı zamanda kullanıcıların yaratıcılıklarını geliştirmelerine, inançlarını gözden geçirip kendilerini tanımalarına ve geliştirmelerine olanak sağladığı, aynı zamanda kişilerin duygusal ve zihinsel süreçleri üzerinde de etkili olduğu ifade edilmektedir (Contreras ve ark., 2015, s.313). Örneğin çocuk ve gençler üzerinde yapılan araştırmalarda Wattpad'i kullanarak yazma ve düşünme becerilerinin artırabildiğine yönelik bilimsel çalışmalar mevcuttur (Jusmaya, 2019; Juniar, Widiati ve Astuti, 2019; Bal, 2018). Wattpad hikayelerini yayınlayan Genç Destek Yayıncısı Özlem Esmergül'de, gençlerin Wattpad platformunda yazmak isteme nedenlerini "kişilerin genciyle yaşlısıyla kendilerini değerli hissetmek noktasında sorunlar yaşadıkları ve bu sorunla baş etmek için geride anlamlı bir hatıra, bir iz bırakmak istediklerini dolayısıyla bu platformun onlara bu imkanı verdiği" şeklinde açıklamaktadır (Börekçi, 2015).

Wattpad'in gençler için özgür bir ifade alanı oluşturmakla birlikte birçok riski de içerisinde barındırdığı ifade edilmektedir. Okuma, yazma ve paylaşımda bulunma alanı sunan Wattpad, gençler üzerinde etkili bir kontrolsüz sanal platform olarak görülebilmektedir (Aytekin ve Yavuz, 
2019, s.506). Özgür hikayeciliğin örneği olarak kendisi taktim eden Wattpad; erotizm, cinsel ve fiziksel istismar, pornografi, madde kullanimı gibi çocukları ve gençleri olumsuz etkileyebilecek içeriklere sahip hikayelerin paylaşılabildiği; bu bağlamda herhangi bir sınırlama veya denetimin olmaması açısından kontrolsüz sosyal platformalar olarak da ifade edilebilmektedir. "Wattpad, Cinsel İstismar ve Pedofili" başlıklı köşe yazısında Kaya (2019) Wattpad'de pornografi, erotizm, pedofili ve şiddet içerikli kitapların olduğuna değinerek bu kitaplardaki karakterlerin narsist, dışlanmış, kuralsız, toplumsal normlara uymayan ve antisosyal davranışlar sergileyen gençleri içermesinin gençler açısından duygusal bağımlılığı ve bağımlı ilişki geliştirmeyi övdüğü ve özendirdiğine dikkat çekmektedir. Buna yönelik olarak Küçük Kızın Sert Adamı, Küçük Karım, Acımasız Kocam, Zoraki Evlilik, Küçüktüm Ama Büyüdüm” gibi hikayeleri örnek göstererek pedofili betimlemesi yapıldığını ve bu tip hikayelerin çok fazla olduğunu vurgulamaktadır. Küresel Wattpad Topluluğu raporunda bu yıl doğaüstü ve fantezi gibi temaların oluşturulmasının hikayelerde eşcinsel, lezbiyen ve LGBTQIAP+ temsillerini artırdığına ve bu temaların amacına ulaştığına yer vermektedir. Öyle ki bu rapora göre 2019 yılında eşcinsel etiketli ve temalı paranormal hikayelerin sayıs1 \%26 ve \#lesbian etiketli paranoral hikayelerde \%100 artış olduğu ifade edilmektedir. Yine 2020 yılında kullanıcıların, geçen yıla göre \#LGBTQ etiketli okumaya 720 milyon dakikadan fazla zaman ayırdığı dolayısıyla okuma oranında \%58'lik bir artışın meydana geldiği bilgisine raporunda yer vermektedir (Wattpad, 2020c).

Ergenlik çağında gençlerin Wattpad'deki karakterlerden ve yaşayış biçimlerinden olumsuz örnekler çıkaracakları endişesini dile getiren A ğır (2017) ise en beğenilen Wattpad kitaplarındaki hikâyelerde yer alan madde kullanımı, sigara ve alkol bağımlılığı, antisosyal davranışlar, kesici alet ve ateşli silah taşıma, cinsel şiddete eğilim, ehliyetsiz araba kullanma, depresyon, okul kurallarına uymama, devamsızlık, düzensiz beslenme ve uyku alışkanlıkları gibi davranışların ergenlerin bakış açılarını etkilediği dahası sosyal ve psikolojik problemlere neden olabildiğini ifade etmektedir. 


\section{Çalışmanın Amacı ve Önemi}

Bu çalışmayla kullanıcıların \%90'ının Z kuşağından ve önemli bir bölümünün çocuklardan meydana geldiği Wattpad Platformunda yer alan ve talep gören hikayelerin içeriklerinin incelenmesi yoluyla çocukların ve gençlerin eğilim, talep ve ilgi alanlarını keşfetmek amaçlanmaktadır. Wattpad'in içerik olarak sunduğu 23 kategoriden birisi ‘Genç Kız Edebiyatı'dır. Wattpad "Genç Kız Edebiyatı" kategorisini, "kendisini modern kadınlığın mücadeleleri ile ilişkilendirir. Genç kız edebiyatında kimi zaman romantik unsurlar bulunsa da, hikayeler genel olarak baş karakter olan kadının arkadaşları ya da ailesi ile olan ilişkilerine odaklanır." şeklinde tanımlamıştır (Wattpad Yardım, 2021). Bu tanımdan anlaşılacağı üzere, Wattpad'de yayınlanan hikayeler "modern kadınlık" bağlamında okuyucularına "genç kız ve genç kadınlara" ilişkin bir temsil oluşturmaktadır. Dolayısıyla hikayelerde yer alan karakter temsilleri, olay örgüleri ve riskli davranış örüntülerini inceleyerek bu temsiller arasındaki ilişkilerin niteliği ve ilişkilerin hangi davranış ve araçlarla yansıtıldığını ortaya koyarak Wattpad ve benzeri sanal platformların $Z$ kuşağı için oluşturduğu avantaj ve riskleri belirlemek çalışmanın bir başka amacıdır.

\section{Yöntem}

\section{Araştırma Yöntemi}

$\mathrm{Bu}$ çalışma nitel araştırma yöntemi şeklinde tasarlanmıştır. Nitel araştırma yöntemi; algıların ve olayların doğal ortamda gerçekçi ve bütüncül bir şekilde ortaya konulduğu, gözlem, görüşme ve doküman analizi gibi farklı nitel veri toplama yöntemlerinin kullanıldığı bir süreçtir (Yıldırım, 1999, s.10). Çalışmanın amacı ve elde edilmek istenen veri setleri düşünüldüğünde nitel araştırma yönteminin araştırmanın daha uygun olduğu düşünülmüştür. 


\section{Örneklem}

Araştırmanın örneklemi; Wattpad'de genç kız edebiyatı kategorisinde yer alan, tamamlanmış ve henüz fiziksel olarak kitap haline gelmemiş 150.000 ve üzeri beğeni alan hikayelerden oluşturmaktadır.

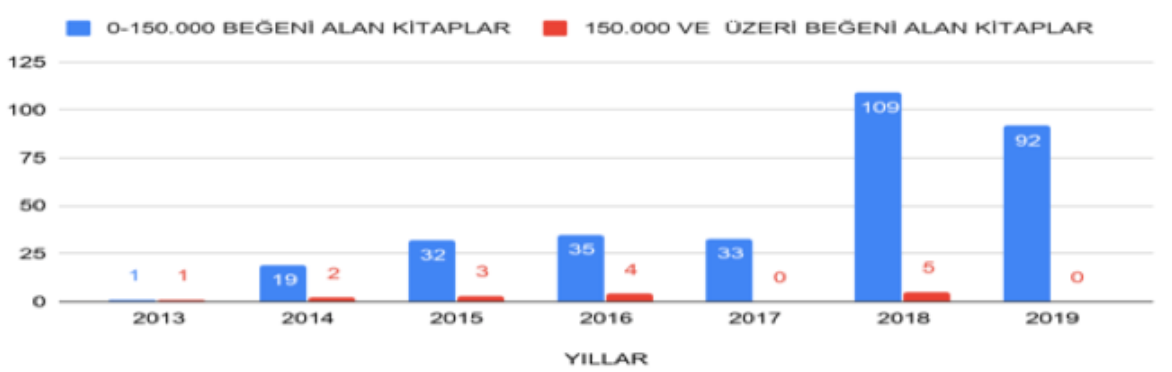

Şekil 1. Tamamlanan Kitapların Yıllar Bazında Bĕ̆eni Sayılarına Göre Dă̆ılımı

30.09.2019-08.10.2019 tarihleri arasında 1336 kitaba ulaşılmıştır. Çalışmanın yöntemine uygun olarak araştırma örneklemine 150.000 ve üzeri beğeni alan toplam 15 kitap girmektedir. Doküman inceleme sürecinde hikayelerin okunma-beğenme sayılarında değişiklikler olduğu gözlemlenmiştir. Yine, bazı hikayelerin kitap olarak basılacak olması sebebiyle yayından kaldırıldığı tespit edilmiş ve bu hikayeler mevcut örnekle kapsamından çıkartılmıştır. İncelenen eserler şunlardır;
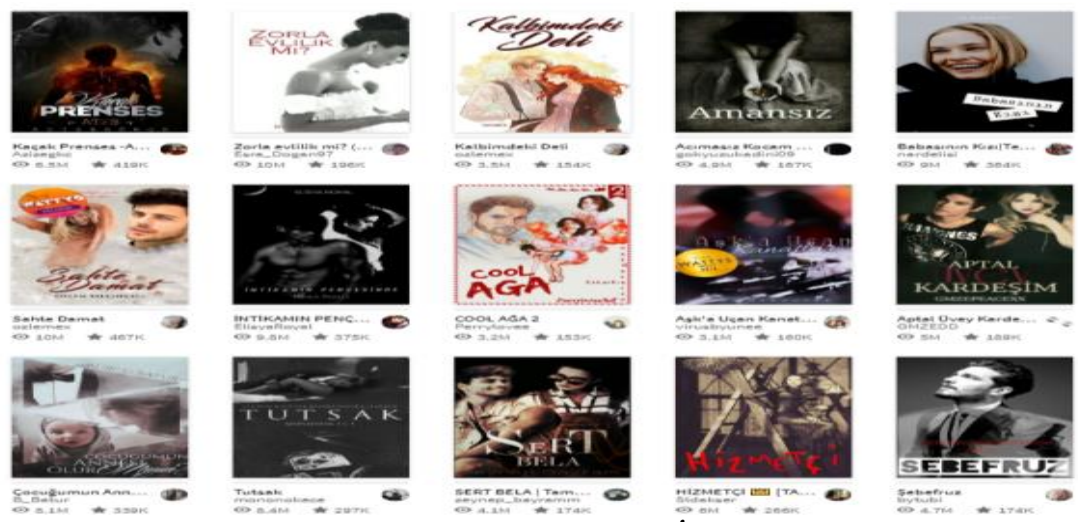

Şekil 2. Araştırma Kapsamında İncelenen Kitaplar 


\section{Veri Toplama ve Analizi}

Örneklem kapsamına giren 15 kitap içerik analizi yöntemi kullanılarak incelenmiştir. Kitapta yer alan her bölüm kendi içerisinde içerdiği konular dikkate alınarak kodlanmıştır. Elde edilen kodlar bir araya getirilmiş en çok değinilen konulara göre temalandırılmış ve alt kırılımlarıyla birlikte 6 tema ortaya çıkmıştır. Bunlar; şiddet, aile, madde kullanımı, riskli davranışlar, hikayelerdeki genç kadın ve erkek karakter temsilleri ve cinsellik ve cinsel davranışlar şeklinde ortaya konulmuştur. Daha sonra çalışmanın yöntemine uygun olarak bulgular ilgili Wattpad metinlerinden temalara uygun olacak şekilde alıntılama yapılarak oluşturulmuştur. Alıntılama sürecinde hiçbir yazım yanlışı ve imla düzeltmesi yapılmamiştır.

\section{Sinırlılıklar}

Araştırmanın örneklemi genç kız edebiyatı kategorisinde yer alan hikayelerden 150.000 ve üzeri beğeni alan, tamamlanan ve henüz kitap olarak basılmamış olmaması şeklinde belirtilmesi ile birlikte hikayelerin beğeni sayılarının günlük olarak artış gösterme ihtimali ve kriterleri sağlayacak yeni hikayelerin araştırma kapsamına alınamaması bu çalışmanın sınırlıliklarından birisidir. Bununla birlikte "kitap olacak" ibaresi yer alan hikayelerde Wattpad'den kaldırılma olasılığının bulunması nedeniyle bu hikayeler tercih edilmemiş ve örneklem içerisine dahil edilememiştir. Son olarak Wattpad'in kullandığı algoritma sebebiyle genç kız edebiyatı kategorisindeki hikaye sayılarının sisteme giriş yapan her araştırmacıda farklı gözükmesi üzerine hikaye sayısının en çok görüldüğü araştırmacının verileri dikkate alınarak örneklem oluşturulmuştur. 


\section{Bulgular}

\section{Demografik bulgular}

Wattpad'de genç kız edebiyatı kategorisinde bulunan hikayelerde yer alan genç kız karakterlerinin betimlemelerini inceleyerek, genç kız temsillerini değerlendirmek amaciyla 30.09.2019-08.10.2019 tarihleri arasında yapılan araştırmada toplam 1336 kitaba ulaşılmıştır. Yapılan çalışmada 150.000 ve üzeri beğeni alan kitaplar ele alınmıştır. Bu bakımdan çalışma 15 kitap üzerinden yürütülmüştür.

Tablo 1. Araştırma Kapsamında İncelenen Kitaplara Yönelik Bilgiler

\begin{tabular}{llll}
\hline HIKAYELER & OKUNMA SAYISI & BEĞENI SAYISI & BÖLÜM \\
Zorla Evlilik Mi? & 10.000 .000 & 95.000 & 101 \\
Çocuğumun Annesi Olur Musun? & 7.700 .000 & 322.000 & 81 \\
Aptal Üvey Kardeşim & 4.700 .000 & 179.000 & 60 \\
Şebefruz & 4.600 .000 & 170.000 & 44 \\
Aşk'a Uçan Kanatlar & 2.900 .000 & 154.000 & 71 \\
Cool Ağa 2 & 3.100 .000 & 152.000 & 51 \\
Kaçak Prenses 1-Ateş & 6.300 .000 & 409.000 & 65 \\
İntikamın Pençesinde & 8.500 .000 & 332.000 & 64 \\
Tutsak & 7.600 .000 & 272.000 & 59 \\
Sert Bela & 4.000 .000 & 173.000 & 63 \\
Sahte Damat & 9.900 .000 & 460.000 & 73 \\
Babasinnn Kızi & 8.000 .000 & 329.000 & 73 \\
Hizmetçi & 5.700 .000 & 259.000 & 49 \\
Acımasiz Kocam 1 ve 2 & 4.800 .000 & 165.000 & 78 \\
Kalbimdeki Deli & 3.400 .000 & 150.000 & 75 \\
\hline
\end{tabular}

Çalışma sürecinde elde edilen veriler; şiddet, aile, madde kullanımı, riskli davranışlar ve kadın/erkek karakter temsilleri ve cinsellik olmak üzere 6 tema altında sunulmuştur.

\section{Şiddet}

Çalışma kapsamında incelenen tüm hikayelerde şiddet olgusunun yer aldığı görülmüştür. Bu başlık içerisinde; şiddet türlerine, fiziksel şiddetin uygulandığı araçlara ve mekanlara, şiddetin faillerinin ve mağdurlarının kim olduğuna ve şiddetin nasıl gerekçelendirildiğine değinilmiştir.

Ele alınan tüm hikayelerde fiziksel şiddetin yanında duygusal, ekonomik ve cinsel şiddet türlerine de rastlanılmıştır. Fiziksel şiddetin tokat 
atmak, vurmak, sıkmak gibi kelimelerle, duygusal-psikolojik şiddetin aşağılama ve küçümseme ile, ekonomik şiddetin kıskançlık, sahiplik ve güç ile, cinsel şiddetin ise güçlü erkek zayıf kadın imgeleriyle ilişkilendirilerek ortaya konulduğu görülmüştür.

"Saçlarımdan tutarak servis tabağındaki yemeklere vurdu. Başımı o kadar hızlı vurmuştu ki ă̆zımdan acı bir inleme çıktı."(Acımasız Kocam, Yemek, Bölüm 9)

"Annem bana sinirle alkış tutarken etrafımda dönmeye devam ediyordu. Bir böcekmişim gibi beni ezen bakışları, aşağılayıcı sesi ve o tanıdık kokusu düşüncelerimi işgal ediyordu."(Kalbimdeki Deli, Hera 46 - 23 Eylül 2014, Bölüm 46).

"'Şirkette onlarca erkek varken seni çalıştırır mıyım?' 'Geçen çalıştırmıştın ama!' 'O geçici süreliğine, hevesini alman adınaydı. Konu kapanmıştır, çalışmıyorsun.' " (Cool Ağa 2, İzin, Bölüm 29)

"O ve onun gibi adam bozmaları, bizim gibi çaresizlerin yalvarışından, acı çekmesinden zeok alırlardı. İlişki esnasında bile, bir kadının canının yanması, bedeninin morluklar içinde kalması, acı dolu çı̆̆lıkları, onlar için bir zeok niteliği taşıyordu." (Çocuğumun Annesi Olur Musun?, Part 1, Bölüm 31)

Elde edilen bulgularda testere, silah, neşter, bıçak, çekiç, sopa, yirmilik lastik, kemer, temizlik malzemesi, sigara ve makasın şiddet aracı olarak kullanıldı̆̆ı görülmüştür.

“Babası ellerini bağlamış ve sırtında sigara söndürüyordu. Öfkeyle doldu. Annesi hiçbir şey yapmamıştı. Evlerine gelen kadınlar susmasını söylüyorlardr." (Acımasiz Kocam, Zaman)

"Gözlerimi açıp bedenime baktı̆̆ımda ciflenmekten her yerim bereli olmuştu." (Acımasız Kocam, Tecavüz, Bölüm 11)

İncelenen metinlerde şiddetin uygulandığ1 mekanlar olarak; depo, orman, kafes, karanlık oda, bagaj, banyo, okul ve işyeri alanlarının kullanıldığı görülmüştür.

"Hera bana anlamsiz gözlerle bakarken benim aklım yeğenim Mercimeğe takılmıştı. Daha bu yaşta okulda kırmadığı kafa kalmamıştı. Bazen düşünüyorum da acaba şiddetli yanı bana mı çekmişti?" (Kalbimdeki Deli, Mahir 27-31 Ağustos 2014, Bölüm 27) 
"Seni direk öldürmek ödül olurdu. Tek başına bu karanlık odada yavaş yavaş öleceksin! Bu tuzlu su seni durmadan yakarken farelerin kan kokusuna gelmesini engelleyecek." (Acımasız Kocam, Bölüm 21)

Hikayelerde failler çoğunlukla erkek karakterlerdir ve kadına şiddet daha çok ailesi ve sevgili tarafından uygulanmaktadır. Karakterlerin sevgili ve aile tarafından uygulanan şiddeti kıyaslarken aile tarafından uygulanan şiddeti daha normal karşıladıkları görülmüştür.

"Bu zamana kadar ne annem, ne babam hiçbirinden tek bir fiske dahi yememişken Ezradan, gelecekte kocam olacă̆ın iddia eden adamdan, nişanlımdan! Bu tokadı yemek çok koymuştu." (Şebefruz, Bölüm 14).

Elde edilen bulgularda şiddet, sevgi göstermenin bir aracı olarak kullanılmış ve erkeğin erkeğe uyguladığı şiddet sevgi ve kıskançlıkla gerekçelendirilmiştir.

"Notu okur okumaz aklıma tek şey gelmişti. Z kişisinin Ŭ̆ur'u dövdüğü. I Arca: Sen yaptın. / Z: Evet. / Arca: Neden diye sormalı mıyım? / Z: Cevabın çok iyi biliyor olmalısın. / Arca: Neymiş? / Z: Çünkü seni seviyorum." (Babasının Kızı, Bölüm 14)

Hikayelerde fiziksel şiddet, bir cezalandırma yöntemi olarak kullanılarak öfke, nefret, intikam gibi duygular ile gerekçelendirilmiştir. Ayrıca sevgili veya arkadaş aracılığıyla cinsel şiddet ve tecavüz sahneleri hikayelerde yoğun olarak betimlenmektedir.

"Bu senin cezan' deyip dişleriyle kulak mememi ısırdı. Ben iyice korkarken kulak mememde biraz daha oyalandr. Kulak mememi bırakıp nefesini üfledi." (Acımasız Kocam, Gözlerime Bak, Bölüm 6)

"Diğer eliyle başımı sabitledi ve dudaklarımızı birleştirdi. Çok sert davranıyordu ve gözümden yaşların süzülmesine sebep oldu. Önce üst dudağımı ardından alt dudă̆ımı emdi. Dudaklarımı talan ederken karşılık bulamamanın sonucunda dudaklarıma dişlerini geçirmişti. Acryla inlemiştim. Metalik bir tat ă̆zımda yayıldığında bunun kendi kanım olduğunu biliyordum. Ömer halinden memnun gibiydi. Başımı sabitleyen elini belimde gezdirmeye başladı. Daha sonra üzerimdeki baskısın arttırarak koluma geçirdi parmaklarmı. Tekrar bir görüntü gözlerimin önünde belirdi." (Kaçak Prenses, Ateş, Bölüm 40) 


\section{Aile}

İncelenen hikayelerde yer alan ailelerin çoğunluğunun ölüm, ayrılma gibi nedenlerle veya aile yaşamında yer alan suçlar nedeniyle parçalanmiş ailelerden oluştuğu görülmektedir. Hikayelerde aile ve ebeveyn kavramına farklı anlamlar yüklenmiştir ve bu yüklenen anlamlar çeşitli duygularla ilişkilendirilerek sunulmuştur. Bu nedenle hikayelerde aile, aile tasvirleri, ailenin parçalanma sebepleri, aile ile ilişkilendirilen duygular ve aile yaşamında yer eden suçlara yer verilmiştir.

Hikayelerde aileler koruyucu ve destekleyici şekilde tasvir edildiği gibi çocuk üzerinde korku ve endişe bırakan otorite sahibi bir baba, aile içinde ilgisiz ve sevgisiz, nefret duygusu ve intikam isteği ile büyütülen çocuk gibi tasvirlere rastlanılmaktadır. Ailelerin koruyucu ve destekleyici şekilde tasvir edildiği hikayelerde çocukların kendilerini güvende hissettikleri, annelerin şefkatli olarak ifade edildiği hikayelerde anneye duyulan özlemin ön planda olduğu, sevgisiz ve ilgisiz bir ailede büyüyen çocuk tasvirlerinde ise gençlerin evliliğe karşı olumsuz bir bakış açısına sahip olduğu görülmüştür.

"Edim sana gerçekten değer veriyor, bununla beraber amcası kulağına nefret sözcüklerini aşıladığı zaman sadece dört yaşındaydı." iç çekti. "Hiçbir çocuk, savaşlar ve ölümler gören bir çocuk kadar hızlı büyüyemez. Üstelik amcası onu çok zorladı, tahmin edebileceğinden bile daha fazla. Yazmayı söktüğ̈̈ zaman defterine yazdı̆̆ı ilk kelime... intikamdı." (İntikamın Pençesinde, İp 43 Gerçeğin Portresi, Bölüm 43)

"Ben annemle babamın hayatına baktıkça asla evlenmeyeceğimi söylerdim. Onların evliliğinde 4 çocuk vardı ama sevgi yoktu." (Sahte Damat, Mehir 33 Aşk Değilse Nedir?, Bölüm 33)

Elde edilen bulgulara göre hikayelerde bulunan aileler ölüm, aldatma ve terk etme gibi sebeplerle parçalanmış ailelerden oluşmaktadır. Ebeveynleri tarafından terk edilmenin gençlerde yarattığı boşluk hissi, nefret ve intikam duygusunu tetikleyerek gençlerin karakterlerine yansıdığı görülmektedir.

“' 'Tamam.' Hilmi Aksoy teslim olmuş bir ifadeyle ona baktr. 'Ne yapacaksan yap ama önce dinle.' Kısa bir nefes ald ve 'Yalvarırım.' dedi. 'Önce dinle.' Sarp'ın bir an durmasin firsat bildi ve onun elindeki silaha büyük bir korku ile 
bakarken; bir saniye bile ara vermeden hızh bir şekilde konuşmaya başladı; 'Ben anneni çok sevdim.' dedi. 'Ama evliydim Sarp. Boşanmamı bekledi ama boşanamadım. Çünkü karım ilk çocuğumuza hamile kalmıştı. Bunu duyduğunda Ayla beni terk edip o şerefsiz babana gitti. Aylar sonra da onunla evlendiğini öğrendim!' " (Tutsak, 2.Kısım, Bölüm 25)

Genel olarak incelenen hikayelerde ailelerin olumsuz tutum ve davranışlarına değinildiği görülmüştür. Hikayelerdeki çocuklar genellikle; sorumluluk ve fedakarlık özellikleriyle veya değersizlik hissiyle birlikte tasvir edilmiştir.

"Masa tekrar eski sessizliğine gömülmüştü. Haklıydım. Başka çaremiz yoktu. Annem için kendi geleceğimi feda ederdim. Edecektim de." (Şebefruz, Bölüm 2)

Hikayelerde ailelerin çocuklarıyla ilgilenmedikleri, onları ikinci plana attıkları, çocuklarını dinlemeden yargıladıkları hatta bazen de onları koruyamadıkları görülmüştür. Bu nedenle aileleri tarafından ilgi görmek ve sevilmek istediklerini ifade eden ve ailesinin ilgisini çekebilmek için intihar eyleminde bulunan genç figürüyle karşılaşılmıştır. Bazı hikayelerde ise gençlerin, aileleri tarafından psikolojik şiddete maruz kalmaları sebebiyle değersizlik ve sevilmedikleri hissine kapıldıkları görülmüştür.

"Ağlamamın sebebi canımın yanması değildi babamın beni dinlemeden yargilayıp haksız yere bana vurmasıydı" (Sert Bela, Bölüm 1)

"Ben bir kitap karakteri değildim. Gerçektim. En basitinden acıyı hissediyordum. Ama ailem sanki ben gerçek değilmişim, duygularım yokmuş gibi davranıyorlardı. Burda benim yok saylmamin tek nedeni vardı oda istenmemek. Evet kocaman olan bu ailede istenmiyordum. Nedensiz yok sayılır miydı insan? Sayıldım... Defalarca varlığım küfürmüş̧ gibi geldi." (Acımasız Kocam, Bölüm 2)

“' 'Yullarca bunu sordum.' dedi titrek sesinin izin verdiği ölçüde bağııırken. 'Yillarca beni mahrum bıraktığın sevginin nedenini sordum. Cevap alamadım... Beni sev diye uğraştım hep, yillarca babam beni sevsin diye kendimi paraladım. Belki ilgini çekerim diye bileklerimi bile kestim!' " (Tutsak, Bölüm 28)

Hikayelerde tecavüz, kumar, kızını satmak, cinayet, kaçakçılık, şiddet, iftira gibi aile yaşamında yer etmiş suçlar ile sıkça karşılaşılmıştır. 
Buna bağlı olarak patolojik aile ilişkileri içerisinde dağılan bir aile yapısının ve kendini değersiz hisseden bir genç figürünün ortaya konulduğu görülmektedir.

"Annemin hastalığının ciddiyetini bildiğim için son günlerinde yanından hiç ayrılmamıştım. O gün hiç duymamam gereken bir şey duydum... Amcam, Anneme... Tecavüz etmiş..." (Hizmetçi, Bölüm 29)

"'Sen bana aitsin. Seni ailenden aldım.' Ailemden almıştı. Haklıydı. Beni ona para karşılığında satmışlardı. Benim sahibimdi. Bunu inkar etmem gerçeği değiştirmiyordu." (Acımasız Kocam, Bölüm 36)

"Ben Defne Öz, Öz ailesinin yüz karasıydım. Ailesinin bile istemediği hayatı boyunca iteklenen acizliğin temsilcisi." (Acımasız Kocam, Bölüm 29)

\section{Madde Kullanımı}

Madde teması altında sigara, içki ve uyuşturucu ile ilgili bulguların yer aldığ1 gözlemlenmiştir. Bu temada; madde türlerine, madde kullanımının nasıl betimlendiğine, maddeye yüklenen anlama, madde kullanılan mekanların tasvirine ve madde kullanımının nasıl gerekçelendirildiğine değinilmiştir.

İncelenen hikayelerde uyuşturucu maddenin hap, zambak ve beyaz kumru şeklinde ifade edildiği, içkinin ise tekila, viski, şarap, votka, şampanya, mextaka, rom, bira, likör gibi çeşitli türlerine yer verildiği görülmüştür.

"Khen işadamı ciddiyetiyle zevzekliğin arasında kalmış bir sesle, 'Sana üç seferdir, parasız zambak veriyorum,' dedi." (İntikamın Pençesinde, Lacivert Gece, Bölüm 1)

"Sarp ise ciddiyetle Lavin'e kısa bir bakış attı ve sonra yeniden Nikos'a döndü ve kendini toparladı. 'Eee o kadar konuştuk; Metaxa içmiyor muyuz bu gece?' " (Tutsak, Bölüm 16)

"Elime iki kadeh alırken likör benzeri bir içkinin, şekili yeşil cam şişesini de diğer elime aldım." (Kaçak Prenses-Ateş, Bölüm 46)

Elde edilen bulgularda madde kullanımının üç farklı şekilde betimlendiği gözlemlenmiştir. İlk olarak; hikayelerde madde kullanımı esna- 
sında yaşanılan hislerin "zevk duymak, tatmin olmak, stres atmak, rahatlamak, hafiflemek" gibi sözcüklerle ifade edildiği, ikinci olarak; madde kullanımı esnasındaki hareket ayrıntılarının "sigarayı dudaklarının arasına almak, dumanı tek çizgi halinde üflemek, dumanı usulca bırakmak, sıvı boğazımdan giderken" gibi ifadelerle belirtildiği ve son olarak ise, madde kullanımıyla özdeşleştirilen davranışların "bardakların tokuşturulması, şampanyayı patlatmak, fondip yapmak" gibi ifadelerle betimlendiği görülmüştür.

"Sigarayı tüttürdükçe, gözlerini kapatıp gökyüzüne doğru gri dumanı bırakıyordu. Tuhaf olansa, yüzünde öylesine tatmin olmuş bir ifade beliriyordu ki, zevkle içiyor gibi görünüyordu. Babası da sigara içerdi, ama böylesi bir zeok aldığını hiç hatırlamıyordu. Sigaranın gri dumanı, rüzgar yönünde olduğu için burnuna doldu. Kaşları çatıldı. Sigara, çok farklı kokuyordu, şimdi niye zeok aldığın anlamıştı. Muhtemelen içinde farklı şeyler vardı ve Tümer sigarayla kafayı buluyordu." (İntikamın Pençesinde, Kovmak, Bölüm 25)

"Sıvı boğazımdan akıp giderken, solistin sesi kulaklarıma doluyordu. Sohbetlerle, gülüşmelerle geçirdiğimiz güzel vakitlerin ardından üzerime düşen uyuşukluk ve mayhoşlukla sanırım ufaktan sarhoş olmuştum." (Şebefruz, Bölüm 30)

“Ezra şampanya şişesini patlatırken gülümseyerek, 'Senin bu şaşkın hallerini seviyorum ben' dedi. Bardaklara doldurduğu şampanyayı elime tutuştururken, burnuma öpücük kondurup geri kaçmıştı." (Şebefruz, Bölüm 33)

İncelenen kitaplardan elde edilen bulgulara göre madde kullanım davranışı yaşanan bir acının ya da ortama uyum sağlamaya çalışmanın sonucu olarak ortaya çıkmaktadır. Buna ilişkin olarak içkinin genellikle sosyalleşmenin ve acıları unutmanın bir aracı olarak kullanıldığı görülmüştür.

"Hayatımı düşündükçe başım ă̆rıyor, başım ağrıdıkça içki şişesini kafama dikiyor, sarhoş oldukça unutuyor ama içtikçe de yeniden ve daha fazla başım ağrıyordu. Bu kısır döngü beni mahvetmişti"(Çocuğumun Annesi Olur Musun?, Bitmiş Bir Hayat, Bölüm 2) 
"Az ileride bir arkadaş grubum var. Eğlenceli sohbetler ve bol biramız var. Oraya gidelim diyoruz, gelmek ister misin?" (Şebefruz, Bölüm 36)

Ele alınan hikayelerde ailesinin dikkatini çekmek isteyen bir gencin yönlendirmeye ne kadar açık olduğu görülmektedir.

"Mavi saçlı kız, kahkaha attı. 'Ay kıyamam, canı da tatlıymış' diye dalgasını sürdürdü. 'O zaman... Hem dikkat çekecek bir şeyler hem de bunları takmayacağın sağlayan bir şeyler dene...' İşte bu ilgisini çekmişti. 'Nasıl şeyler?' 'Hap. Hap kullanabilirsin. O haplar küçük ama etkisi bir sihir gibi büyülü ve büyük.' " (İntikamın Pençesinde, Bölüm 18)

İncelenen hikayelerde elde edilen bulgulara göre hikayelerdeki bar, meyhane, gece kulübü gibi mekanlar gençlerin istedikleri gibi dans edebildikleri, madde kullanabildikleri ve toplumun ahlaki değerlerine uymak zorunda olmadıkları eğlence amaçlı uğranan mekanlardır. Bu mekanların tasvirleri hikayelerde şu şekilde yapılmıştır:

“Tuna'yla birlikte kulüpten içeri girdiğimizde ortama kısa sürede olsa adapte olamadım. İçerisi resmen bok gibi kokuyordu. Her yerde delice dans eden manyaklar ve kulübün neredeyse bütün köşelerinde birbirlerine dil banyosu yapan ve yiyişen insanlar vardl. Ah, Tuna'nın takıldı̆̆ı mekanlar nasıl olur ki zaten?" (Aptal Üvey Kardeşim, Bölüm 8)

“Kumar oynayanlar, bar kısmında kadınlarla eğlenenler, bir köşede uyuşturucu kullananlar... Tüm pis işlerin döndüğü bir krallıktı burası ve ben bu krallığın sahibiydim" (Şebefruz, Bölüm 29)

Elde edilen bulgulara göre hikayelerde bu mekanlara girebilmek için belli bir yaş sınırı olduğundan bahsedilmekte fakat karakterlerin bu yaş sınırına uymadıkları ve kolayca bu mekanlarda zaman geçirebildikleri görülmektedir.

"Kapının önünde 2 tane badigard duruyordu. Ama Tuna'yı görünce yaşımızı bile sormadan önümüzden çekildiler ve bizde rahatça içeri girdik" (Aptal Üvey Kardeşim, Bölüm 7) 


\section{Riskli Davranışlar}

Elde edilen bulgularda intihar düşüncesine sahip olan ve intihar girişiminde bulunan genç karakterlere, kendine zarar vermenin bir biçimi olarak ortaya çıan yaralamaya ve toplumsal kurallara uymama durumuna sıkça rastlanılmıştır. Bu nedenle riskli davranışlar kategorisi kapsamında toplumsal kuralsılık, intihar ve kendini yaralama gibi eylemlerin de incelenmesine gerek duyulmuştur. İntihar ile ilgili olarak; intihar sebeplerine, intihar araçlarına ve intihar ile duygu durum arasındaki ilişkiye değinilmiştir.

İncelenen eserlerde aile, aşk, itibar, gebelik depresyonu ve dikkat çekme gibi durumlar intihar sebepleri arasındadır. İntihar sebebi olarak aşk ve aile konusu karşımıza çıkmaktadır. Hikayelerdeki karakterler için aşk, uğrunda canından bile olacak kadar üstün bir konumda bulunmaktadır. Bu nedenle karakterler aşık oldukları insanı kaybetmenin sonucunda veya aşık oldukları insanın dikkatini çekmek ve kendisine bağlanmasını sağlamak amacıyla intihar etmektedir. Karakterlerin intihar etme sebeplerinden bir diğeri ise intiharın, aileden kaçış yolu olarak düşünülmesidir. Dolayısıyla hikayelerde aile ve aşk ile ilişkili sorunları çözmenin yolu ve sevginin bir kanıtı olarak intiharın tercih edildiği görülmektedir.

" 'Kokuna geliyorum' titrek sesiyle fisildayarak kendini boşluğa doğru serbest bıraktı. Bal gözlü adam tatlı belası olmadan yaşayamazdı. Kalplerine mühürlenen aşkları ateşte kavruluyordu. Kadın gitti. Adam bitti..." (Sert Bela, Bölüm 42)

"Kendimi öldürecektim başka çaresi yoktu. Hayır dedim diye bunu yapan ailem kaçmam sonucunda kendi elleriyle öldürürlerdi. Nereye gidersem gideyim beni bulacaklardı. Bazen en iyi kaçış yok olmaktı. Yok olmaktı bir yaprak 8 tanesi gibi. Savrulmak zordu pes etmek kolay çünkü acılar fazla derindi. Kaçışım ölümümdü. Ben ölmeyi seçtim. Tek çözüm ölümdü ve ben bunu seve kabul ettim." (Acımasız Kocam, Bölüm 2)

Elde edilen bulgulara göre dört farklı intihar aracına rastlanılmıştır. $\mathrm{Bu}$ intihar araçları silah, araba, uçurum, jilet veya cam parçası olarak 
belirlenmiştir. Hikayelerde jilet veya cam parçasıyla bilekleri keserek intihar etme davranışına ise daha sıklıkla rastlanılmaktadır.

"Kapıyı açtığımda ise korkunç bir manzaranın beni beklediğinden habersizdim. Ahsen cam vazoyu kırıp bileklerini... Bileklerini kesmişti! Allah kahretsin ki yine aynı şeyi yapmıştı. Yanına koştuğumda ise bir kağıdın üstünde yazan yazıyı gördüm önce "Sana daha çok vicdan azabı çekeceğini söylemiştim!" (Çocuğumun Annesi Olur Musun?, Bölüm 4)

İntihar; bir kıyaslama, ölüme değer atfetme, çaresizlik, değer biçme, değer verme ve çözümsüz olduğu düşünülen duygu durumların betimlenmesi gibi durumlar için kullanılmıştır. Bununla birlikte, ana karakterin kendi ölümü ile ilişkilendirdiği çözümler ve çözümsüzlükler, karakterin kendine verdiği önemi göstermektedir.

"Hele ölüm isteğgi... Kendisi henüz o noktaya gelmemişti fakat kafasının içinden bileklerine uzanan intihar fikri hep içinde bir yerde, belki zihninin herkese kapalı olan yerinde, istiridye kutusundaki inci kadar değerle büyüyor, parlıyor ve kıymet kazanıyordu." (İntikamın Pençesinde, Bölüm 43)

Karakterlerin kendine zarar verme biçimi olarak ortaya çıkan kendini yaralama durumu hikayelerde aşk, öfke, boş vermişlik duyguları ile ilişkilendirilerek sunulmuştur. Bu açıdan elde edilen bulgularda, riskli davranışlarda bulunan karakterlerin sözleri bu riskli davranışların rahatlatıcı olduğu yönünde mesajlar içermektedir.

"İç sesimi daha fazla duymamak için avucumu bütün gücümle sıkmaya başlamıştım. Kendime zarar verdiğim zaman sanki rahatlıyordum." (Aptal Üvey Kardeşim, Bölüm 45)

Hikayelerde ortaya çıkan kurallara uymama hali ise duygu durumu ile ilişkilendirilerek sunulmuştur. Elde edilen bulgularda daha çok depresif olma ve güçlü hissetme duyguları, hız sınırını aşmak kavramı ile ifade edilmiştir.

"Yanından geçtikleri tabelada yazan hız sinırın gördü o an ve alt dudă̆ın dişledi. Çoktan; sınırın iki katına çıkmıştı bile... Ve bu tuhaf bir şekilde iyi his- 
settiriciydi. Yanlış şeyler yapmanın da; insana keyif veren bir yönü olduğunu fark etti o an, bu nedenle. Hız sinırların aşmak, bedenini zehirleyen bir maddenin tadına bakmak, kuralları çiğnemek; bazen yaşadığım hissetmenin iyi bir yoluydu." (Tutsak, Kısım 2, Bölüm 36)

\section{Hikayelerdeki Genç Kadın ve Erkek Karakter Temsilleri}

Hikayelerde kadın ve erkek karakter temsilleri bağlamında; öğrenilmiş kadınlık ve erkeklik olgusu ve idealize edilmiş beden temsillerinin aktarımları incelenmiştir.

İncelenen hikayelerde öğrenilmiş toplumsal cinsiyet rollerinin kadın ve erkek arasında hiyerarşik bir yapı oluşturacak biçimde kurgulandığ 1 görülmektedir. Hikayelerin bazı kısımlarında bu durumun açı bir şekilde ortaya konulmasıyla birlikte hikayelerin bütününün bu zeminde yapılandığı söylenebilir.

"Oğlum hadi bunlar kız bunları anlarımda bize ne oluyor lan? Neden kız gibi üzülüp ağlamakl bir sahne oluşturup vedalaşıyoruz. " (Aşk'a Uçan Kanatlar, 1. Bölüm)

"Başım dönmeye devam ederken Koray a karşı koyamıyordum. Kadın olmanın çaresizliğini yaşıyordum." (Acımasız Kocam, Yemek, Bölüm 9)

"Soğuktan çenem birbirine vursa da Koray da hafif titreme bile yoktu." (Acımasız Kocam, Beşiktaş'ın Maçı Var, Bölüm 32)

"Bir kadını güzel yapan güzel seven erkektir. Seni kaybetmekten çok korkuyorum Mahir." (Kalbimdeki Deli, Mahir 55-18 Mart 2016, Bölüm 55)

Yazarların, erkek bedenini "mükemmel" şekilde, kadın bedenini ise daha kaygılı bir biçimde betimlemeleri hem kadınlara hem de erkeklere yükledikleri ağır toplumsal cinsiyet rollerini işaret etmektedir. Wattpad hikayelerindeki baş kahramanların tümünün idealize edilmiş kadınerkek algisına uygun bir biçimde sunulması, bu hikayeleri yazan ve okuyan kişilerin kendilerine rol model aldıkları temsillere ilişkin belirli ipuçları vermektedir. 
"Yüz hatlarn uyurken bile sertti ama bu sertliğin yanında bir de masum, savunmasız haylaz bir çocuk vardı. Kıvrımlı ve dolgun dudaklarl, kalın ve biçimli kaşları, çıkık elma kemikleri ile gerçekten yakışıklıydı. Mafya olamayacak kadar yakışıkı hem de." (Şebefruz, Bölüm 5)

"Az daha uzun olsam, Sema gibi falan olsam fena olmazdı hani. Yine de bücürmüyüm ki ben ya? 1.65 çokta kısa değil. Fakat 1.88-1.87 olarak düşününce galiba bücürüm ben. Ya bu pilotlar neden bu kadar uzun? Cidden çok kısamıyım? Öyleyim galiba..." (Aşk'a Uçan Kanatlar, Bölüm 16)

“Vandor dan aldığı cevap şöyleydi. 'Ben kas bă̆lamış elinde kılıç taşıyan kadına kadın demem. Kadın dediğin narin olmalı. En büyük silahı kalplere zarar gülüşü olmalı.' " (Kaçak Prenses-Ateş, Bölüm 27)

"Endişe ve merakla karısının ameliyat haneden çıkmasını bekleyen Batı Ă̆a

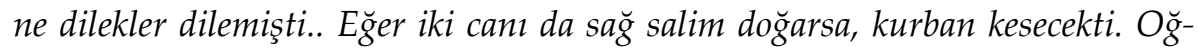
luyla beraber şirketler yönetecekti... Ona bir kıza nasıl sahip çıkılacă̆ını öğretecekti. Daha da önemlisi kıskanç yetiştirecekti." (Cool Ağa 2, Doğum, Bölüm 20)

\section{Cinsellik}

Ele alınan hikayelerde cinsellik olgusuna ilişkin birçok bulgu elde edilmiştir. Bu başlık altında kadın ve erkek karakterlerin cinselliği algılama ve yaşama şekillerine, cinselliğin kadın ve erkek olmak hali ile ilişkisine, kadınların ve erkeklerin cinsellik bağlamında nasıl karakterize edildiğine ve erkek ve kadın karakterlerin cinsellik ile ilişkilendirilen namus algısına değinilmiştir.

Hikayelerdeki genç kadın karakterlerin cinsel ilişki aktarımında, erkek karakterlerin beklentilerine göre deneyimin şekillenmesine sıkça rastlanılmıştır.

"'Saten geceliğini neden giymiyorsun?' tek kaşım kalkarken 'Neden giyeyim ki?' dedim gülerek. Yerinde daha da gerindi. 'Kocanı memnun etmek için.'” (Cool Ağa 2, İzin, Bölüm 29)

Hikayelerde erkek karakterlerin şehvetli olma hali bir erkeği tamamlayan ve tanımlayan bir özellik olarak sunulmaktadır. Erkek karakterler 
için cinsellik, tıpkı şiddet olgusunda olduğu gibi, bir güç kaynağı olarak ele alınmıştır.

"O ve onun gibi adam bozmaları, bizim gibi çaresizlerin yalvarışından, acı çekmesinden zeok alırlardı. İlişki esnasında bile, bir kadının canının yanması, bedeninin morluklar içinde kalması, acı dolu çı̆̆lıkları, onlar için bir zevk niteliği taşıyordu." (Çocuğumun Annesi Olur Musun?, Part 1, Bölüm 31)

Hikayelerde erkek karakterlerin cinsellik ile olan ilişkisi şehvet duygusu ile birlikte sunulurken kadın karakterlerin cinsellik ile olan ilişkisi romantizm ile ilişkilendirilmiştir. Bununla birlikte bekaret algısına dair bakış açılarının da yansıtıldığı metinlerle karşılaşılmıştır:

" 'Anladık, uzatma.' dedi Batı. 'Kızlara karşı aşık rolü yapmak ve işim bittiğinde onları terk etmek; uzmanlik alanım zaten. Asıl sen dikkat et de rolümün gücünden etkilenip bana aşık olma.' " (Tutsak, Bölüm 43)

" 'Bilmiyorum Çă̆an, olmuyor işte.' dedi Lavin. Bekaret denilen şeyi önemsediği için değildi. Yalnızca Çă̆an'la bunu ne kadar denerse denesin, onunla ne kadar yakınlaşırsa yakınlaşsın daha fazlası olmuyordu. Belki ten uyumu dedikleri şey gerçekti. Belki de Çă̆an'ın çok da kibar olmayan tavırları onu farkında olmasa da itiyordu ama sebebi her neyse; bedeni de ruhu da kendisini bunu yapmaya Çağan'la hazır hissedemiyordu. Çă̆an sinirle ona bakarken 'Sikıldım artık şu hallerinden.' diye bağırdı ve ayağa firladı. 'İki yakın arkadaşmışız gibi takılmaktan bıktım! Evlenince yapabilecek miyiz peki bunu sence? Yoksa bütün ömrümüz bu ön sevişmelerden mi ibaret olacak? Sıkmaya başladı bu iş gerçekten.' " (Tutsak, Bölüm 3)

Hikayelerde yer alan cinsel içerikli anlatımlarda detaylı tasvirlerde bulunulurken erkek karakterlerin davranışın faili olarak yansıtıldığı ve sorumluluk yüklendiği görülmektedir. Elde edilen bulgularda kadın karakterler cinsel ilişkiyi başlatan değil, daha çok başlayan bir sürece uyum sağlayan yapıda betimlenmiştir.

"Doğanın elleri rahat durmuyor, beni daha da çok çıldırtmak için bornozumun yakasindan tutup, yavaş yavaş açıyordu. Omuzuma öpücükler kondurmaya dalmışken, ben kendimden çoktan geçmiştim. Daha fazla dayanamayıp bornozumu çıkartıp odanın bir köşesine firlatmıştı." (Zorla Evlilik Mi?, Bölüm 57) 
Benzer doğrultuda kadın karakterlerin cinsel yaşama ilişkin talep eden değil razı olan taraf olarak betimlenmesi ve bu razı olma halinin kadın karakterlerin nazlı ve/veya cilveli, masum ve naif olmaları ile ilişkilendirilmesi dikkat çeken bir diğer husustur.

“Öpüşümü biraz daha derinleştirdiğimde Didem bu kez fazlasıyla karşılık vermeye başlamıştı. Demek ki Didem'in çenesini sıkarak tehdit etmek gerekiyormuş yoksa nazından öpüşüp koklaşmaya geçemeyecektik." (Kalbimdeki Deli, Mahir 5-20 Haziran 2014, Part 2, Bölüm 5)

Hikayelerde yoğun ve detaylı olacak şekilde cinsellik içeren gösterimler aktarılmaktadır. Bununla birlikte cinsel birlikteliklerin sunumunda 'erkeklik' ve 'kadınlık' olarak ifade edilen cinsiyet kalıplarının cinsel organlar ve cinsel eylemler üzerinden yeniden üretildiği görülmektedir.

"Dilim yavaşça ... doğru yol alırken işi daha da eğlenceli kılmak için biraz ara verdim ve sol elinin orta parmağını alıp ă̆zıma götürdüm. Yavaş ve sıcak bir şekilde parmağını ă̆zımda hareket ettirirken Tuna'nın erkekliğinin kabardığın gördüm." (Aptal Üvey Kardeşim, Sarhoş, Bölüm 52)

"Sol elini, onun iç çamaşırının içine ... ; dolanmadan dümdüz bir şekilde kasıklarını sıyıran eli, ... kadınlığına yerleşince, Lavin titrercesine panikledi; sanki şimşek çarpmış gibi, kalçası yükseldi. Yaşadığımız dünyanın ardında, uzak geri planda başka bir dünya o an önüne uzandr; gerçek dünyadan farkll, daha hafif, daha havai." (İntikamın Pençesinde, İp 45 Gece Tutulması, Bölüm 45)

Analiz edilen hikayelerde kadın karakterlerin cinsel açıdan erkeğe yetip yetmeme gibi bir kaygıyı da barındırdığı görülmektedir.

"Titreyen dudaklarmm arasindan fisiltıyla "Yatakta da benden iyi mi?" diye sordu. Hamiyet'in tek derdi bu muydu?" (Kalbimdeki Deli, Mahir 9-26 Haziran 2014, Part 3, Bölüm 9)

Kadın karakterlerin cinselliğini ve kadınlığını erkek karakterleri hayatında tutmak, yapmak istedikleri bir şeyi gerçekleştirmek ve eşleri ya da sevgililerini cezalandırmak için bir araç olarak kullanması toplumdaki erkek ve kadın ilişkisi algısının çarpıklığına ilişkin önemli çıkarımları içinde barındırmaktadır. 
"Evet, ikinci aşamamız; eğer erkeğin seni dinlemiyorsa o zaman elinde olan kadınlığının gücünü kullan!... " (Aptal Üvey Kardeşim, Bölüm 41)

Cinselliğin kadın ve erkek karakterler açısından namuslu olma hali ile ilişkilendirilmesine ve namus kavramının kadın üzerinden aktarılmasına hikayelerde oldukça sık rastlanılmaktadır. Kadının kendi cinsel dürtülerine yabancı olma hali ve bu halin getirdiği utanma duygusunun yanı sıra namus kavramı tamamen cinsel birliktelik ile ilişkilendirilmiş bununla birlikte namus kavramının toplumsal tanımına yönelik eleştiriler dile getirilmiştir.

"Birbirimizden farkl, iki zıt karakter olmamıza rağmen, enteresan bir biçimde birbirinin aynisıydık. Mesela benim 'şey'diye bahsettiğim eylemi kendisi büyük bir rahatlıkla dile getirebiliyordu, bu onun açık sözlülüğ̈̈̈nden kaynaklanan bir şeydi." (Şebefruz, Bölüm 33)

"Ne demek ne fark ediyor. Sen sanıyor musun? Ben böyle bir kızı sevgilim yaparım. Yanımda taşırım?" demesiyle tokat atmam bir oldu. Hepsi aynıydı işte hepsinin aklı oradaydı. Ne sanıyorlar namus iki bacak arsinda mı? Masum kızlar ne olacak başına gelenler... Onlara da mı kötü gözle bakıyorlardı... Asıl namussuz şerefsiz olanlar o pisliği yapanlardı..." (Hizmetçi, Bölüm 21)

\section{Tartışma ve Sonuç}

Z kuşağı için teknoloji bir araç olmanın dışında çok farklı anlamlar da taşımaktadır. Z kuşağına göre teknoloji, fikirlerini genişlettikleri, toplumsal değişim süreçlerini etkileyebildikleri, kendilerini rahatlıkla ifade edebildikleri bir alandır. Kim olduklarını gösterebildikleri ve toplumun kendilerine ihtiyaç duyduğu fikrini var eden bu teknolojik araçlar bu kuşağın kendini güçlü hissetmesini sağlamaktadır (Sladek ve Grabinger, 2013, s.5).

Z kuşağının teknoloji ile ilgili deneyimlerine ilişkin yapılan bir araştırmada katılımcıların dörtte üçü teknolojiyi hedeflerine ulaşmalarına yardımcı olan; üçte ikisi ise kendilerine her şeyin mümkün olduğunu düşündüren bir araç olarak tanımlamıştır. Aynı araştırmada Z kuşağ 1 için "teknoloji ve onun araçlarının" geleceğe hazırlanmak, bilgi aktarımı ve fikirlerin paylaşımı gibi eğitsel amaçlar dışında eğlenmek, keyif almak 
ve kendini daha iyi hissetmek gibi duygusal amaçlara da hizmet ettiği aktarılmaktadır (Singh, 2014, s.63). Dolayısıyla Z kuşağı okuma ve yazma eylemini yukarıda ifade edilen amaçlar çerçevesinde bir araya getirerek eğlence kültürünün yanında küresel bir okuma kültürü de oluşturduğu belirtilmektedir (Pianzola, Rebora ve Lauer, 2020, s.2). Araştırmanın veri havuzunu da oluşturan, teknolojinin ve yeni nesil gençlik edebiyatının iş birliği ile oluşan Wattpad gibi sanal platformların Z kuşağı için sadece yazım platformlarının ötesinde çok daha farklı anlamlara karşılık geldiği açıtır. Bu araştırmayla, dijital okuma-yazma sitesi olan ve popüler hale gelen Wattpad platformunda yer alan 'genç kız edebiyatı' kategorisindeki en çok okunan ve beğeni alan kitapların incelenmesi suretiyle (okuyucu/tüketici) gençlerin ilgi alanlarının, yönelimlerinin izini sürerek $Z$ kuşağının kendilerini ifade etme biçimlerindeki dönüşümlerin ve karşı karşıya kaldıkları riskli davranış ve temsillerin neler olduğunu tespit etmek amaçlanmıştır. Araştırma kapsamında 150.000 ve üzeri beğeni sayısına ulaşmış, tamamlanmış ve henüz kitap olarak basılmamış 15 hikaye incelenmiş ve şiddet, cinsellik, aile, madde kullanımı, riskli davranışlar ve genç kadın/erkek karakter temsilleri olmak üzere bulgular 6 temada sunulmuştur.

Araştırma sonucunda genç kız edebiyatı kategorisinde yer alan hikayelerin önemli bir kısmı genç kızların duygusal çatışma ve bunalımları üzerine odaklanmaktadır. Hikaye örgüleri incelendiğinde karakterlerin bu sorunlara karşı intihar, şiddet, kendini yaralama, riskli cinsel davranışa yönelme vb. davranışsal çözümler ürettikleri tespit edilmiştir. Çocukların ve gençlerin gelişimlerini etkileyecek çok sayıda olumsuz içerikle karşılaşılmıştır. Özellikle cinselliğin, madde kullanımının, şiddet ve türlerinin ve olumsuz aile örüntülerinin açık ve yoğun şekilde hikayelerde tasvir edildiği ve okuyucular tarafından yüksek beğeni aldığı görülmüştür. Wattpad platformu, erişim ve tüketim noktasında $\mathrm{Z}$ kuşağına ulaşmayı kendilerine kurumsal bir hedef olarak seçtiklerini ve bugün kullanıcılarının \%90'ının Z kuşağından ve önemli bir kısmının ise 18 yaş altı bireylerden oluştuğunu açklamaktadır. Dolayısıyla Wattpad hikaye/roman içerikleri başta çocukların olmak üzere bilişsel, psikolojik ve sosyal açıdan gelişim sorunlarına ve riskli davranışlara yol açabileceği düşünülmektedir. Gelişim sorunlarına ve riskli davranışların ortaya çıkmasına neden olabilecek durumlardan birisi çocukların ve gençlerin 
rol model edinme ihtiyacıdır. Davranışın öğrenme yoluyla gerçekleşebildiği düşünüldügüünde hikayelerde öne çıkartılan kahramanların yoğun bir şekilde olumsuz davranış ve söylemlerde bulunması, çocukların istenmeyen davranışları kolaylıkla örnek almalarına ve buna yönelik davranış modelleri geliştirmelerine neden olabilmektedir. Dolayısıyla çocuğun kişiliğinin belirlemesinde önemli bir etken olduğu bilinen rol modeller hikayeler üzerinden üretilerek ve pazarlanarak okuyucularının büyük çoğunluğunu oluşturan çocuklar tarafından satın alınabilme ve riskli davranışlarda bulunma noktasında özendirici ve cesaretlendirici bir etki ortaya çıkarabilmektedir. Kauffman ve Lippy (2012)'in yaptıkları çalışmada da Wattpad yazarlarının birbirlerine yakın yaş gruplarında olmaları ve gerçek yaşamlarında benzer sorun ve problemler yaşamaları, gençlerin birbirlerinin hikayelerini okuyup beğenmelerinde ve bu hikayelerle ilgili paylaşımlarda bulunmalarında önemli bir etken olduğu, bu platformda gençlerin rahatlıkla kendi hikayelerini oluşturabildikleri fakat denetime tabi tutulmadan yayınlanan bu hikayelerin kurmaca olduğu bilinse de gençleri önemli ölçüde etkilediği yönünde sonuca ulaşılmiştır (Çoban, 2015, s.595). Ayrıca çocukların keşfetme arzuları ve merak duyguları, kendi yaşlarına uygun olmayan kitapları okumalarına sebep olabilmektedir. 12-13 yaşlarındaki genç kızların 17-18 yaşlara hitap eden kitapları okumaları kendilerine sunulmuş olan idealize figürle özdeşlik kurmalarına sebep olmaktadır. Kurdukları bu özdeşlik, hikayedeki kahramanların yaşlarına geldiklerinde hayal kırıklıkları yaşamalarına neden olabildiği bilinmektedir. (Neydim, 2011, s.20)

Hikayelerde kadınlık ve erkekliğe, kadın olmak ve erkek olmaya yönelik oldukça zengin betimlemeler bulunmaktadır. Tasvir edilen hikayelerde kadın ve erkek söylemlerindeki hegemonik söylemin ve anlayışın varlığ1 yeni bir nesil olarak tanımlanan $\mathrm{Z}$ kuşağında da büyük oranda kendisini göstermektedir. Hikayelerde, genç kızların gözünden erkek karakterler güçlü olma hali ile ilişkilendirilmektedir. Erkek karakterlerdeki gücün kötüye kullanımı -ahlaki normlar dışında kalsa da travmatik bir geçmiş ile gerekçelendirilerek rasyonalize edilmektedir. Hikayelerdeki kadın karakterlerin monologlarındaki erkek karakterlerin şiddete eğilimli olma halinin, kadın karakterlerce sevilen özelliklere işaret eden anlatımlar içermesi, genç kızların sevmeye, aşık olmaya yükledikleri anlama dair bir ipucu sunmaktadır. Kadın-erkek ilişkilerinin büyük 
oranda cinsellik üzerinden kurgulandığı ve betimlendiği görülmektedir. Erkek karakterler için tıpkı şiddet olgusunda olduğu gibi cinsellik de bir güç simgesi olarak gösterilmektedir. Cinsel davranışlarda ve konuşmalarda erkek karakterler rahat şekilde kendilerini ifade edebilirken kadın karakterlerin ifadelerinin çekinceli ve utangaç şekilde yansitıldı̆̆ı görülmektedir. Bununla birlikte hikayelerde erkek cinselliği şehvet ve arzu ile birlikte sunulurken, kadın cinselliği romantizm ve duygusal yoğunlukla ilişkilendirilmektedir. Bu hikayelerdeki kadın karakterler cinselliği başlatan değil, başlayan bir sürece uyum sağlayan olarak konumland1rılmıştır. Kadın, talep eden değil razı olan taraf olarak betimlenmekte ve bu razı olma hali kadın karakterlerin masumiyeti ve naifliği ile ilişkilendirilmektedir. Erkek karakterlerde ise şehvetli olma hali, bir erkeği tamamlayan ve tanımlayan özellik olarak sunulmuştur. Cinsel organlar "erkeklik" ve "kadınlık" kelimeleriyle ifade edilmektedir. Kadının cinsel açıdan erkeğe yetip yetmemesi de metinlerde yer almaktadır. Bazı hikayelerde ise kadınların cinsellik algısının; erkeği elde etmek, istediklerini yaptırmak ve partnerlerini cezalandırmak için bir araç olarak kullanmak şeklinde olduğu görülmektedir. Ayrıca cinsellik kadın karakterler açısından namuslu olma hali ile de ilişkilendirilmiş olup namus kavramı kadın üzerinden ifade edilmektedir. Dolayısıyla Wattpad platformundaki bu metinler hegemonik erkekliğin, cinsiyetçi söylem ve yaklaşımların yeniden üretildiği yerler olması açısından da önemlidir (Messerschmidt, 2019; Akar, 2019).

Müstehcenlik, hikayelerde sıklıkla yer alan olumsuz unsurlardan birisidir. Kadın ve erkek arasındaki romantik ilişkiler sıklıkla cinsel birleşmelerle ve bunların detaylı tasvirleriyle sunulmaktadır. Bu yönüyle hikayelerde büyük oranda erotik ve pornografik bir aktarımın olduğu görülmektedir. Wattpad kitaplarının içerik analizlerinin yapıldığı araştırmalarda çok sayıda olumsuz unsurun tespit edildiği özellikle de cinsellik ve müstehcenliğin en sık karşılaşılan unsurları olduğu tespit edilmiştir (Güleç-Sağlam, 2020, s.91; Ağır, 2019, s.737). Neşeli ve Yiğitbaşı'nın (2020, s.20) çalışmasında da Wattpad kitaplarında benzer şekilde cinsel ögelere ve pornografik anlatımlara sıklıkla rastlandığ 1 ifade edilmektedir. Öyle ki Wattpad okuyucularıyla yapılan bir başka çalışmada katılımcıların yaklaşık \%55'i hikayelerin hepsinde ya da çoğunluğunda şiddet ve cinsellik konularının sıklıkla işlendiğini belirtmektedir (Yiğitbaşı, 
2018, s.33). Çalışmada tecavüz ile ilgili birçok içerikle de karşılaşılmaktadır. Kadının rızasının alınmadığı, zorla veya baskıyla alındığı veya duygusal manipülasyon sonucunda razı edildiği cinsel birleşmeler hikayelerde yer almaktadır. Hikaye içeriklerinde fiziksel şiddet sıklıkla yaralama şeklinde; duygusal-psikolojik şiddet aşağılama ve küçümseme; ekonomik şiddet ise erkeklerin kadının çalışmasına izin vermeyerek kadınları tahakküm altına almaları şeklinde yansıtılmıştır. Buna ek olarak şiddetin kıskançlık, intikam, sevgi vb. duygularla gerekçelendirilerek okuyucuya sunulduğu görülmektedir. Şiddetin araçlarına bakıldığında sopa, testere vb. araçların kullanıldığı, şiddetin uygulandığı mekanlara bakıldığında ise kafes, bagaj gibi kapalı ve ıssız mekanların ifade edildiği görülmektedir. Erkek karakterler kaba, cebir kullanan, kötü ve müstehcen davranışlarda bulunan ya da bulunmaya yatkın kişiler olarak betimlenirken; kadın karakterler ise masum, ezilen ve çoğu zaman itaatkar olarak betimlenmektedir.

Üç Wattpad romanını merkeze alarak yapılan bir araştırmada da benzer sonuçlara ulaşılmıştır. Belirtilen çalışmada benzer şekilde erkek temsiller "kötü erkek", kadın temsiller ise "masum kız" şeklinde sunulmaktadır. Bununla birlikte erkeklerin güçlü, zengin, tehlikeli, çekici, kaba oldukları ve masum kızları sahiplendikleri; kadınların ise masum, duygusal, yalnız, ailesiyle sorunları bulunan, korunmaya ihtiyacı olan şekilde yansıtıldığ 1 tespit edilmiştir (Özkan, 2020, s.102). Çalışmamızın başında, Z kuşağının yazdığı hikayelerde ve okuyucu kitlesinde cinselliğin temsilinde toplumsal cinsiyet eşitsizliğinin ve ataerkil düşünce ve pratiklerin sınırlı olacağı tahmin edilirken 'geleneksel' olarak ifade edilen bu düşüncelerin ciddi şekilde kendisine yer bulduğu görülmektedir.

İncelenen hikayelerin anlatımlarında patolojik aile ilişkilerinin sıklıkla tasvir edildiği ve kadın-erkek ilişkilerinde hiyerarşik bir tutumun yansitıldığı görülmektedir. Bununla birlikte ailenin parçalanmış olma durumuna sıklıkla rastlanılmaktadır. Bu patolojik aile ilişkileri karşısında yaşanılan yok sayılma ve çaresizlik hissi, hikayelerde net bir şekilde ortaya konulmuştur. Ayrıca ailelerin çocuklarına suçluluk duygusu yükledikleri de metinlerde görülmektedir. Tüm bu olumsuz aile ilişkileri gençlerin aitlik duygusunu zedelemekte, gencin onay ve kabul gereksinimlerinin karşılanmaması sonucunda hem sosyal olarak hem de psikolojik olarak sorunlar yaşamasına sebep olmaktadır. Buna ek olarak okunan 
hikayelerde ailesini erken yaşta kaybeden bir karakterin aile yapısı da ütopik özelliklerle sunularak bu tür aile yapısının kusursuzlaştırıldığı görülmektedir. Anlatımlar arasında, ailenin var olduğu durumlarda sorunlu ilişkilerin yoğunluğu söz konusudur ve yapılan norm dışı eylemlerin gerekçesi aile ile ilişkilendirilmektedir. Ailenin var olmadığ 1 durumlarda ise bu eylemlerin gerekçesi olarak ailenin yokluğu ve kimsesizlik hissinin verildiği görülmekte; bu durum ailenin, hikayeleri yazan gençlerin hayatını şekillendirmedeki etkisini ortaya koymaktadır. Pianzola, Rebora ve Lauer'in çalışmasında da (2020, s.33) özellikle batı dillerinde yazılan hikayelere karşılık asya dillerindeki hikayelerde "aile" ilişkilerine daha fazla atıfta bulunulduğu tespit edilmiştir.

Hikayelerde alkol ve madde kullanımına yönelik yoğun bir içerik bulunmaktadır. Sigara, alkol ve uyuşturucu madde kullanımı çoğu zaman özendirici bir şekilde yansitılmaktadır. "Madde kullanımı" mutlu olmakla veya üzüntülü olmakla özdeşleştirilmektedir. Aynı zamanda hikayelerde bu maddelerin kullanımından "zevkle içme, kafayı buldurma, geçtiği her bir hücreyi rahatlatma" gibi betimlemelerle bahsedilmesi çocuklar ve gençler için merak uyandırabilmektedir. Hikayelerde yer alan madde kullanımının sebepleri incelendiğinde; karakterlerin bazen yaşadıkları sorunları unutmak için bazen de dışlanmamak ve sosyalleşmek için madde kullandıkları görülmektedir. Hikayelerde madde kullanmak zor bir hayat yaşamanın sonucunda büyüyüp olgunlaşmak ile madde kullanmamak ise incinebilirlik ve masumiyet ile ilişkilendirilmiştir. Alkol ve madde kullanımının, içinde bulundukları aile değerlerine, geleneksel değerlere ve "sıradanlaşmış" yaşantılara karşı özgürlüğün, isyanın ve kendisini kanıtlamanın bir aracı olarak kullanıldığ tir. Wattpad platformunda en çok okunan on kitabın incelendiği bir araştırmada benzer şekilde alkol ve uyuşturucu kullanmak, şiddet uygulamak gibi olumsuz davranışlar ve kötü alışkanlıkların öne çıktı̆̆ı sonucuna ulaşılmıştır (Karaosmanoğlu, 2019). Yine Wattpad hikayelerinden oluşan ve yayınevleri tarafında basılmış 5 kitabın incelendiği bir araştırmada da alkol, sigara gibi zararlı maddelerin yoğun olarak kullanıldığ 1 ifade edilmektedir (Neşeli ve Yiğitbaşı, 2020, s.19). Farklı bir çalışmada ise hikayelerde yer alan madde ve alkol kullanımının özgürleşmek, rahatlamak, kendisini kanıtlamak, öfke gibi duygularla ilişkilendirildiği bulunmuştur (A ğır, 2019, s.737). 
Wattpad'de yer alan kitapların içeriklerinde öne çıkan temaların ve konuların tespitinin yapılması $Z$ kuşağı okuyucularının eğilimlerinin ve yönelimlerinin anlaşılabilmesi açısından da önemli bir veri olma özelliği taşımaktadır. Bu bağlamda incelenen kitaplarda 'eşler ve sevgililer arasinda şiddet, akran ve sevgili zorbalığı, argo sözler, cinsellik, aşk, aldatma, tecavüz, madde kullanımı' gibi temaların sıklıkla yer aldığı ve okuyucu hedef kitle tarafından yoğun bir şekilde tüketildiği görülmektedir. Wattpad hikayeleri, başlarda var olan talebe karşı oluşturulmuş bir arz olsa da sonrasında talebi şekillendirecek biçime büründüğü söylenebilir.

Araştırma sonucunda en sık işlenen konulardan birisinin de "aşk ve romantik ilişkiler" olduğu görülmektedir. Farklı dillerde ve ülkelerde yazılmış Wattpad hikayelerinin incelendiği kapsamlı bir araştırmada "aşk" (amor,love, omour, amore, cinta) kelimesinin hikayelerde en sık kullanılan kelime olduğu tespit edilmiştir (Pianzola, Rebora ve Lauer, 2020, s.10). Wattpad'de yer alan romantik hikaye kategorisi okuyucularıyla yapılan bir çalışmada da katılımcıların önemli kısmının eğlenmek için, romantik ilişkilere duyulan ihtiyacın hikayeler yoluyla karşılanmasına yönelik içsel istek nedeniyle ve romantik ilişkilerde ortaya çıkan karmaşık sorunlara yönelik çözüm yollarını keşfetmek amacıyla hikayeleri okudukları sonucuna ulaşılmıştır (Basri, Tamrin ve Afriyanti, 2019, s.11). Ülkemizde Wattpad okurlarıyla yapılan bir araştırmada da katılımcların Wattpad hikayelerini tercih etmesinin ikinci sebebi olarak "heyecanlı ve romantik konular" işlenmesi bulunmuştur (Yiğitbaşı, 2018, s.29). Gerek ifade edilen araştırmalarda gerekse yaptığımız araştırmamızda aşk ve romantik ilişkiler konulu içeriklerin ortak ve yaygın olarak üretildiği veya tüketildiği görülmektedir. Kadın-erkek ilişkilerinin daha sık sorgulanabildiği, duygusal eğilimlerin ve arzuların, romantik birliktelikler ve duygusal örüntülerin merak konusu olabildiği şeklindeki ergenlik dönemi özellikleri Wattpad kullanıcılarının yaş özellikleriyle birlikte düşünüldüğünde benzer tema/konulu hikayelere talep ve eğilimin nedeni daha kolay anlaşılabilecektir.

İntihar davranışı veya söylemi kitaplarda öne çıkan riskli davranışlar arasında kendisine önemli bir yer bulmaktadır. Suna ve arkadaşlarının (2005) araştırmasına göre 15-24 yaş arasındaki gençlerin intihar etme ve intihar girişiminde eğiliminde bulunma sıklıkları diğerlerine göre daha yüksektir. İntiharı düşünsel ve sözel boyutta daha sık kadınlar, eylemsel 
boyutta ise erkekler davranış haline getirmektedir (Cüceloğlu, 2010, s.456). Lise ve üniversite öğrencilerinin örnekleme dahil edildiği bir araştırmada gençler arasında intihar düşüncesi ve davranışının yaygın olduğu, en az bir defa intiharı düşünmüş olduğunu bildiren kadınların sayısı erkeklerin sayısına göre anlamlı olarak fazla olduğu sonucuna ulaşılmıştır (Eskin, 2017, s.106). Wattpad'in kullanıcı profili düşünüldüğünde metinlerde intihar imgesinin bu kadar yoğun kullanılmasının dikkate alınması gerektiği düşünülmektedir. Bununla beraber, metinlerde ailevi sorunların yoğun işlendiği de göz önüne alınırsa intihar davranışının oluşmasına zemin hazırlayabilecek bir unsurun varlığından söz etmek mümkündür. Zira aile sorunlarının intihar noktasında önemli bir değişken olduğu bilinmektedir (Yıldız ve Akça, 2015, s.17; Eskin, 2017, s.94; Palabıyıkoğlu, 1993). Genç kız edebiyatı kategorisinde yer alan kitapların analizi sonucunda, aile sorunlarını ve ilişkisel sorunları çözme yolu olarak intihar etme eylemine oldukça sık başvurulduğu; özellikle de genç kızların intihar eyleminde veya söyleminde bulundukları yansıtılmaktadır. Türk edebiyatında aşk yüzünden intihar etme olayının sıkça görüldügüunü, içinde bulunduğu sorunu çözemeyen gençlerin intiharı bir çözüm olarak gördükleri belirtilmektedir (Üstten, 2016, s.612) Benzer şekilde kitaplarda yer alan hikaye örgülerinde en çok karşılaşılan intihar sebebi aşk ile ilişkilidir. Hikayelerdeki çocuk ve gençler, aşık oldukları kişiyi elde etmek ve onun tarafından önemsenmek istemekte; aşkı ve aşık oldukları kişiyi hayatlarının merkezine koymaktadırlar. Sonuç olarak, patolojik bir sevgi ve aşk duygusu ortaya çıkmaktadır. Metinler üzerinde aile sorunları/romantik ilişkiler, riskli davranışlar ve intihar üçgeninde yeni bir okuma yapılması durumunda Wattpad okuyucusu gençler için intihar davranışına ilişkin meşruiyeti oluşturacak, bunun görünürlüğü artıracak unsurlara maruziyetin dikkate alınması gereken bir nitelik taşıdığı düşünülmektedir.

Hikayelerde yer alan içerikler Z kuşağının yönelimleri, beklentileri ve taleplerine dair ipuçları barındırmaktadır. İçeriklerin çocuk ve ergenler üzerindeki olumsuz etkilerinin yanı sıra bu kuşağın dilini, düşüncesini ve beklentilerini anlama; karşılaştıkları ailevi, ilişkisel ve duygusal problemlerin neler olduğunu ve bu sorunlarla nasıl baş ettiklerini keşfetme imkanı da sağlamaktadır. Z kuşağının hikayelerde yansıttığı bu temsillerde sevgisiz ailelerde büyümek, parçalanmış ailelere sahip olmak ve 
arkadaş ilişkilerinde asosyal kişiler haline gelmek gibi psikolojik ve sosyal sorunların varlığına dair önemli ipuçları vermektedir. Bu açıdan Wattpad ve benzeri platformlar, ergenlerin ve çocukların kendilerini ve sorunlarını ifade etmelerinin bir aracı haline geldiği görmezden gelinmemelidir. Wattpad uygulamasinda yer alan hikayeler, hem ergenlerin bakış açısıyla yazılması hem de okuyucu kitlesinin büyük bir çoğunluğu çocuk ve ergen bireylerden oluşması bakımından önemli bir veri kaynağıdır. Son olarak, çocukların tükettikleri içerik ve görsellerin (Film, dizi vb.) gelişimleri açısından ne kadar önemli olduğu bilindiği kadar, aynı çocukların ne tür sanal platformlarda ve ne tür içeriklerle karşı karşıya olduğunun da aileler ve eğiticiler tarafından bilinmesi oldukça önem arz etmektedir. Kullanıcılarının büyük bir kısmı çocuklardan meydana gelen Wattpad platformu suç, şiddet, intihar gibi risk davranışlara, madde türleri ve kullanımına, erken yaşta cinsel deneyimlere, pornografik içeriklere ve sağlıklı olmayan aile yaşantılarına tanık olma ve özendirme konusunda ciddi bir risk oluşturmaktadır. Çocukların dizi ve film izlemeleri için gelişim özellikleri dikkate alınarak oluşturulan içerik derecelendirme sistemine benzer bir şekilde söz konusu sanal platformlarında denetimlerinin yapılarak kullanıcıların ve ailelerin bilgilendirileceği yöntemlerin geliştirilmesi önemlidir. 
EXTENDED ABSTRACT

\section{The Attempt of Authorship in Generation Z: An Investigation of Character and Behavioral Representations in Stories in the the Young Girl Literature Category on Wattpad Platform}

Burak Acar- Zehra Karahan- Gülseren Yalçın- Ayşe Nur Yorulmaz- Ömer Miraç Yaman Istanbul University-Cerrahpasa

Generation $\mathrm{Z}$-the creator, producer, and inventor, but also the consumer generation- reinterprets past habits and tools through virtual platforms and creates their own culture. Writing styles, one of the habits of children and young people when it comes to expressing themselves, are transferred to virtual platforms by Generation Z, resulting in new production and consumption understandings. Wattpad, which brings the reading culture and literary works together, is one of these products. The aim of this research is to analyze the most read and liked books in the category of 'young girls' literature' on the digital literacy site Wattpad platform, which has become really popular, and to identify the transformations of the way generation $\mathrm{Z}$ expresses themselves, the risky behaviors they face, and their representations by tracing the interests and orientations of young people (readers/consumers). In this context, the document analysis method, -one of the qualitative research methods- has been used in this study. In accordance with the method of the study, a total of 15 books that received 150,000 or more likes have been included in the research sample. Each chapter in the books has been coded considering the topics it contains. These codes have been brought together, and then themed according to the most mentioned topics, and in the end, 6 themes emerged with their sub-breakdowns. In accordance with the method of the study, the findings were created with the quotes of the relevant Wattpad texts in accordance with the themes. Pathological family representations, representations of men and women based on gender roles, risky behaviors such as substance use, crime, violence, suicide, sexual intercourse at an early age, pornographic presentations, sexual violence such as rape are the prominent content features in these stories. 
In all the themes that have been created, the narrations made in the context of male and female representations, learned femininity and masculinity, and idealized body perceptions are at the forefront. In these stories, many findings have been obtained regarding the phenomenon of sexuality, which is presented as a means of these narrations. Romantic relationships between men and women are often presented in detailed descriptions in the context of sexual intercourse. Under this title, the ways in which male and female characters perceive and experience sexuality, the connection of sexuality with being a woman and a man, how women and men are characterized in the context of sexuality, and the perception of honor associated with sexuality of male and female characters are mentioned. Violence appears to be a symbol of power for male characters, just like the phenomenon of sexuality. Various types of violence were included in these stories, the tools of violence and places where physical violence was committed, the depiction of the perpetrator and the victim, and the justification of the violence were reflected. In addition, it is seen that the majority of the families in the stories that have been analyzed consist of families that were broken due to reasons like death, separation or crimes within the family life. In the narratives, it is seen that pathological family relationships are frequently depicted, and a hierarchical attitude is reflected in male-female relations. The feelings of being ignored and helpless in the face of these pathological family relationships are clearly revealed in the stories. Different meanings have been attributed to the concept of family and parent, and these meanings have been given in association with various emotions. For this reason, the family, family descriptions, the reasons for breaking up the family, the feelings associated with the family and the crimes within the family life are often included in the stories. One of the other issues that is mentioned is substance use. Under the substance theme, the types of addictive substances such as cigarettes, alcohol, and drugs in the stories, how the substance use is described by the main characters, the meanings attributed to the substance, the description of the places in which the substances are used and how the substance use is justified are mentioned. Another issue that emerged as a risk factor in the findings is the narrations of suicide. Injury as a form of self-harm and non-compliance with social rules are frequently encountered in young characters who 
have suicidal ideation and who attempt suicide. For this reason, it was found necessary to analyze actions like social irregularity, suicide, and self-harm within the scope of risky behaviors category. Regarding suicide, the reasons for suicide, means of suicide and the relationship between suicide and mood have been touched upon. The majority of the stories in the category of young girls' literature, which are included in the sample of the research, focus on the emotional conflicts and depressions of young girls. When we analyze the story patterns, we see that the characters produce risky behavioral solutions such as suicide, violence, self-harm, risky sexual behavior etc. to these problems. In these stories, many negative contents that will affect the development of children and young people has been encountered. In particular, we can see that sexuality, substance use, types of violence and pathological family patterns were clearly and intensely depicted in the stories and were highly appreciated by the readers. These representations reflected in the stories of Generation $\mathrm{Z}$ provide important clues about the existence of psychological and social problems such as growing up in loveless families, fragmented family patterns and becoming asocial in friendships. In this respect, it should not be ignored that Wattpad and similar platforms have become a tool for adolescents and children to express themselves and their problems. The Wattpad platform, which has mostly adolescents and children as users, poses a serious risk in witnessing and encouraging due to its negative content. It is important to develop methods that will inform the users and families by controlling them on the said virtual platforms, similar to the content rating system created by taking into account the developmental characteristics of children concerning watching TV series and movies. However, the existing books are a large data pool for understanding the thoughts and expectations of the Generation $\mathrm{Z}$, discovering what family, relational and emotional problems they face, how they deal with these problems and the ways they try to solve them.

\section{Kaynakça/References}

Ağır, M. (2017, 19 Ocak). Yeşilay wattpad'in gizli tehlikelerine karşı aileleri uyaruyor. Yeșilay, Wattpad' in Gizli Tehlikelerine Karșı Uyarıyor I Yeșilay (yesilay.org.tr). 
Ağır, M. (2019). Sosyal ağ platformu wattpad uygulamasının ergenlerin problemleri, çözüm stratejileri ve olası etkileri açısından incelenmesi. Akdeniz Eğitim Araştırmaları Dergisi, 13(27), 723-752. https://dx.doi.org/10.29329/mjer.2019.185.35.

Akar, G. (2019). Gender discourse in wattpad as a youth subculture. (Yüksek Lisans Tezi). Yeditepe University,Institute of Social Sciences, İstanbul.

Alanka, Ö. ve Cezik, A. (2016). Dijital kibir: Sosyal medyadaki narsistik ritüellere ilişkin bir inceleme. TRT Akademi, 1(2), 548-569.

Arslan, B. ve Nur, E. (2018). Teknolojinin yeni çocuğu: K kuşağı. Avrasya Uluslararası Araştırmalar Dergisi, 6(15), 329-347.

Asutay, H. (2000). Türk ve alman gençlik yazınında ergenlik romanı. (Doktora Tezi). İstanbul Üniversitesi, Sosyal Bilimler Enstitüsü, İstanbul.

Aytekin, M. ve Yavuz, B. B. (2019). Wattpad'in lisede eğitim gören kız öğrenciler üzerindeki etkisi. Sosyal Araştırmalar Ve Dauranış Bilimleri Dergisi, 5(8), 503-512.

Babacan, M.E. (2015a). Sosyal medya ve gençlik. İstanbul:Açlım Kitap.

Babacan, M. E. (2015b). Gençliğin sosyal medya kullanım pratikleri ve sosyal sermaye ilişkisi. Gençlik Araştırmaları Dergisi, 3(2), 37-65.

Bal, M. (2018). Reading and writing experiences of middle school students in the digital age: wattpad sample. Internationel Journal of Education $\mathcal{E}$ Literacy Studies, 6(2), 89-100.

Basri, T., Andi, F. ve Afriyanti, Y. (2019). The reception of selected female readers toward romance story in the wattpad. The 4th Annual Seminar on English Language Studies (ASELS).

Bazarcı, S. (2019). Transmedya uygulamalarında yayılma kanalları: Küresel örnekler üzerine bir inceleme. Akdeniz Üniversitesi Illetişim Fakültesi Dergisi (AKiL), 31, 560-576. https://dx.doi.org/10.31123/akil.529067.

Börekçi, G. (2015, 26 Temmuz). Wattpad yazarları başlı başına bir gezegen. (Habertürk). https://m.haberturk.com/yazarlar/gulenay-borekci/1107552-18-altiwattpad-yazarlari-basli-basina-bir-gezegen adresinden erişildi.

Common Sense Media, (2017). The common sense census: Media use by kids age zero to eight. Research Report.

Contreras, D. J., Gonzaga, H. G., Trovela, B. M. ve Kagaoan, M. A. (2015). The "wattyfever": Constructs of wattpad readers on wattpad's role in their 263 lives. LPU Laguna Journal of Arts and Sciences Communication Research , 308-327.

Cüceloğlu, D. (2010). İnsan ve davranışı. İstanbul:Remzi Kitabevi. 
Çalışı, G., ve Çakıcı, F. O. (2015). Toplumsal cinsiyet bağlamında sosyal medyada kurulan benlik inşasının temsili. Turkish Studies, 10(10), 267290. http://dx.doi.org/10.7827/TurkishStudies.8525.

Çoban, O. (2015). Yoksa sen daha okumadın mı?: Bir online okuma platformu olarak wattpad ve sanal dünyanın gençlerinde sanal okuma kültürü. II. Uluslararası Gençlik Edebiyatı Sempozyumu, İstanbul, Maltepe.

Duse, C. S. ve Duse, D. M. (2016). The teacher of the generation Z. The European Proceedings Of Social \& Behavioural Sciences, Edu World 2016 - 7th International Conference. http://dx.doi.org/10.15405/epsbs(2357-1330).2017.5.2.

Engin, A. O. (10 Eylül 2013). Sosyal medya gençleri kimlik krizine sokuyor. (NTV). 3 Ocak 2021, https://www.ntv.com.tr/turkiye/sosyal-medya-genclerikimlik-krizine sokuyor,u3d4 tzO10WTwGRUriiADg adresinden erişildi.

Ekşi, F. ve Ümmet D. (2015). Bir kişilerarası iletişim problemi olarak internet bağımlılığı ve siber zorbalık: Psikolojik danışma açısından değerlendirme. Değerler Ĕ̆itimi Dergisi, 11(25), 91-115.

Eskin, M. (2017). Gençler arasında intihar düşüncesi, girişimi ve tutumları. Türk Psikoloji Derneği, 32(80), 93-111.

Fırat, M. ve Ayran, G. (2016). Üniversite öğrencileri arasında sanal zorbalık. TAF Preventive Medicine Bulletin, 15(4), 322-329. http://dx.doi.org/10.5455/pmb.1-1450776947.

Google (2016, August). Generation Z: New insights into the mobile-first mindset of teens. http://storage.googleapis.com/think/docs/GenZ Insights All teens.pdf.

Güngör, A. ve Koçak, O. (2020). Üniversite öğrencilerinin akıllı telefon bağımlılığı ve akademik erteleme davranışı arasındaki ilişkinin incelenmesi. Eğitim ve Toplum Araştırmaları Dergisi, 7(2), 397-419.

Güleç Sağlam, S. (2020). Kitap olarak basılan wattpad hikâyelerindeki dinî ve ahlâk̂̂ unsurlara yönelik içerik analizi. (Yüksek Lisans). Bursa Uludağ Üniversitesi, Sosyal Bilimler Enstitüsü, Bursa.

Jusmaya, A. (2019) The effectiveness of using wattpad to develop students' writing ability. Jurnal Ide Bahasa, 1(2), 105-114.

Juniar, R. F., Widiati, U. ve Astuti, U. P. (2019). The effect of using wattpad on process-genre approach towards writing achievement in tertiary level. Jurnal Pendidikan, 4(7), 897-905.

Horzum, M. ve Ayas, T. (2014). Orta öğretim öğrencilerin psikolojik belirtilere göre sanal zorba ve sanal mağdur düzeylerinin yordanması. Online Journal of Technology Addiction and Cyberbullying, 1(2) , 21-36. 
İnselöz, N. T. ve Uçanok, Z. (2013). Ergenlerde sanal zorbalık: nedenler, duygular ve baş etme yollarının niteliksel analizi. Türk Psikoloji Yazıları, 16(32), 20-44.

Kara, M. (2015, 12 Kasım). Türkiye 3 milyon kullancistyla wattpad'in en popüler olduğu üçüncü pazar. https://webrazzi.com/2015/11/12/turkiye-3-milyonkullanicisiyla-wattpadin-en-populer-oldugu-ucuncu-pazarl adresinden erişildi.

Karaosmanoğlu, P. (2019). Wattpad kitapları üzerine bir içerik çözümlemesi. (Yüksek Lisans Tezi). Trabzon Üniversitesi, Lisansüstü Eğitim Enstitüsü, Trabzon.

Kavuk, M. (2011). Ilköğretim öğrencilerinin sanal zorba ve sanal kurban olma durumlarmın incelenmesi. (Yüksek Lisans Tezi). Ankara Üniversitesi, Eğitim Bilimleri Enstitüsü, Ankara.

Kaya, E. (2019, 31 Mayıs).Wattpad, cinsel istismar ve pedofili. Star. https://www.star.com.tr/acik-gorus/wattpad--cinsel-istismar-ve-pedofili-haber-

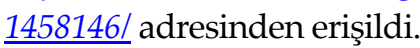

Keleş, H. N. (2011). Y kuşağı çalışanların motivasyon profillerinin belirlenmesine yönelik bir araştırma. Organizasyon ve Yönetim Bilimleri Dergisi, 3(2), 120-137.

Kocaşahan, N. (2012). Lise ve üniversite öğrencilerinde akran zorbalı̆̆ı ve sanal zorbalık. (Yayınlanmamış Yüksek Lisans Tezi). Balıkesir Üniversitesi, Sosyal Bilimler Enstitüsü, Balıkesir.

Messerschmidt, J. M. (2019). Hegemonik erkeklik: formülasyon, yeniden formülasyon ve genişleme. İstanbul: Özyeğin Üniversitesi Yayınları.

Neşeli, D ve Güran-Yiğitbaşı, K. (2020). Türkiye'de yayınevleri tarafından yayınlanan wattpad kitapları üzerine bir araştırma. Yeni Medya Elektronik Dergi, 4(1), 10-23.

Neydim, N. (2011). Gençlik edebiyatı tanım ve uygulama sorunları. İçinde Ĕğitim Sen Gençlik Edebiyatı Ve Genel Edebiyat Kitap Kataloğu (s.13-23). http://egitimsen.org.tr/wp-content/uploads/2015/12/13-26.pdf adresinden erişildi.

Okur, H. (2013). Gençlik ve sosyal paylaşım siteleri. Düşünce Dünyasında Türkiz Siyaset ve Kültür Dergisi, 1(23), 93-106.

Özkan, A. (2020). Geleneksel anlatı tiplerinin popüler romanlardaki dönüşümü: wattpad örneği. (Yüksek Lisans Tezi). Fatih Sultan Mehmet Vakıf Üniversitesi, Lisansüstü Eğitim Enstitüsü, İstanbul. 
Palabıyıkoğlu, R. (1993). İntihar davranışında ailenin rolü ve önemi. Kriz Dergisi, 1(2). https://doi.org/10.1501/Kriz 0000000020.

Pianzola, F., Rebora, S. ve Lauer, G.(2020). Wattpad as a resource for literary studies. Quantitative and qualitative examples of the importance of digital social reading and readers'comments in the margins. PLoS ONE, 15(1). https://doi.org/10.1371/journal.pone.0226708.

Rothman, D. (2016). A tsunami of learners called generation $\mathrm{Z}$. http://www.mdle.net/Journal/A Tsunami of Learners Called Generation Z. $\underline{p d f}$ adresinden erişildi.

Sarıoğlu, E. B. ve Özgen, E. (2018). Z kuşağının sosyal medya kullanım alışkanlıkları üzerine bir çalışma. Uluslararası Sosyal Araştırmalar Dergisi, 11(60), 1067-1081.

Seemiller, C. ve Grace, M. (2019). Generation z: A century in the making. Routledge Taylor\&Francis Group.

Sifferlin, A. (2015, 25 Nisan). 6-month-old babies are now using tablets and smartphones. (Time).http://time.com/3834978/babies-use-devices/ adresinden erişildi.

Singh, A. (2014). Challenges and issues of generation Z. IOSR Journal of Business and Management (IOSR-JBM), 16(7), 59-63.

Sladek, S., ve Grabinger, A. (2013). Gen Z. Introducing the first Generation of the 21st Century.

Tweng, J. M. (2013). Ben nesli. İstanbul: Kaknüs Psikoloji.

Türk Dil Kurumu: Kuşak kavramı. https://sozluk.gov.tr/.

Türkiye İstatistik Kurumu (2020). Hane halkı bilim teknolojileri kullanım araştırmasi raporu, https://data.tuik.gov.tr/Bulten/Index? $p=$ Hanehalki-BilisimTeknolojileri-(BT)-Kullanim-Arastirmasi-2020-33679 adresinden erişildi.

Üstten, A. (2016). Gençlik edebiyatı eserlerinde gençlik sorunlarının yansıtılış biçimi üzerine bir değerlendirme. Turkish Studies, 11(20), 605-616.

Valkenburg, P. M., Schouten, A. P. ve Peter, J. (2005). Adolescents' Identity Experiments on the intenet. New Media E Society, 7(3), 383-402.

Vural, B. A. ve Bat, M. (2010). Yeni bir iletişim ortamı olarak sosyal medya: Ege üniversitesi iletişim fakültesine yönelik bir araştırma. Journal of Yaşar University, 20(5), 3348-3382.

Yıldırım, A. (1999). Nitel araştırma yöntemlerinin temel özellikleri ve eğitim araştırmalarındaki yeri ve önemi. Eğitim Ve Bilim Dergisi, 23(112), 7-17.

Yıldız, S. ve Akça S. (2015). Adolesanlarda risk alma davranışı ve adolesanlara yaklaşım. Psikiyatri/ Nörolojil Davranış Bilimleri Dergisi, 6, 14-22. 
Yiğitbaşı, K. (2018). Transmedya hikayeciliği'nde wattpad örneği ve okur tercihlerine yönelik bir araştırma. Online Academic Journal of Information Technology, 9(30), 21-41.

Yoesoef, M. (2019). Cyber literature: Wattpad and webnovel as generation z reading in the digital world. Advances in Social Science, Education And Humanities Research, 453, 128-131.

Wattpad. (2020a). About wattpad. https://company.wattpad.com/. Erişim Tarihi: 25 Aralık 2020.

Wattpad. (2020b, 10 March). Wattpad named to fast company's annual list of the world's most innovative companies for 2020. 15 Aralı 2020, https://company.wattpad.com/blog/2020/3/10/wattpad-named-to-fastcompanys-annual-list-of-the-worlds-most-innovative-companies-for2020? utm source=prEutm medium=pr email\&utm campaign=mkt year in review release adresinden erişildi.

Wattpad. (2020c, 1 December). Wattpad's 2020 year in review: Catharsis through creativity, creating community, and changing the world with stories. $\quad(20$ Aralık 2020). https://company.wattpad.com/blog/2020/12/1/wattpads-2020-year-in-reviewcatharsis-through-creativity-creating-community-and-changing-the-worldwith-stories adresinden erişildi.

Wattpad Yardım (2021, 15 Şubat), İçerik kategorileri (t.y.) https://support.wattpad.com/hc/tr/articles/360020325871$\% \mathrm{C} 4 \% \mathrm{BO} \% \mathrm{C} 3 \%$ A7erik-Kategorileri adresinden erişildi.

\section{Kaynakça Bilgisi / Citation Information}

Acar, B., Karahan, Z., Yalçın, G., Yorulmaz, A. N. ve Yaman Ö. M. (2021). $Z$ kuşağının yazarlık denemesi: Wattpad platformunda yer alan genç kız hikayelerindeki karakter ve davranış temsillerinin incelenmesi. OPUS- Uluslararası Toplum Araştırmaları Dergisi, 18(43), 7368-7410. DOI: 10.26466/opus.894500. 